\title{
Molecular diversity patterns among various phytoplankton size-fractions in West Greenland in late summer
}

\author{
Stephanie Elferink ${ }^{\mathrm{a}, *}$, Stefan Neuhaus ${ }^{\mathrm{a}}$, Sylke Wohlrab ${ }^{\mathrm{a}}$, Kerstin Toebe ${ }^{\mathrm{a}}$, Daniela Voß ${ }^{\mathrm{b}}$, \\ Marc Gottschling ${ }^{\mathrm{c}}$, Nina Lundholm ${ }^{\mathrm{d}}$, Bernd Krock ${ }^{\mathrm{a}}$, Boris P. Koch ${ }^{\mathrm{a}, \mathrm{e}}$, Oliver Zielinski ${ }^{\mathrm{b}}$, \\ Allan Cembella ${ }^{\mathrm{a}}$, Uwe John ${ }^{\mathrm{a}}$ \\ a Alfred Wegener Institute, Helmholtz Centre for Polar and Marine Research, Am Handelshafen 12, 27570 Bremerhaven, Germany \\ b Institute for Chemistry and Biology of the Marine Environment, University of Oldenburg, Carl-von-Ossietzky Str. 9-11, 26129 Oldenburg, Germany \\ ${ }^{\mathrm{c}}$ Department Biologie, Systematische Botanik und Mykologie, GeoBio-Center, Ludwig-Maximilians Universität, Menzinger Straße 67, 80638 Munich, \\ Germany \\ d Natural History Museum of Denmark, University of Copenhagen, Sølvgade 83S, DK-1307 Copenhagen K, Denmark \\ e University of Applied Sciences, An der Karlstadt 8, 27568 Bremerhaven, Germany
}

\section{A R T I C L E I N F O}

\section{Keywords:}

454 Pyrosequencing

Aquatic communities

Arctic

Biodiversity

DNA-barcoding

Phytoplankton community

Pelagic environment

\begin{abstract}
A B S T R A C T
Arctic regions have experienced pronounced biological and biophysical transformations as a result of global change processes over the last several decades. Current hypotheses propose an elevated impact of those environmental changes on the biodiversity, community composition and metabolic processes of species. The effects on ecosystem function and services, particularly when invasive or toxigenic harmful species become dominant, can be expressed over a wide range of temporal and spatial scales in plankton communities. Our study focused on the comparison of molecular biodiversity of three size-fractions (micro-, nano-, picoplankton) in the coastal pelagic zone of West Greenland and their association with environmental parameters. Molecular diversity was assessed via parallel amplicon sequencing the 28S rRNA hypervariable D1/D2 region. We showed that biodiversity distribution within the area of Uummannaq Fjord, Vaigat Strait and Disko Bay differed markedly within and among size-fractions. In general, we observed a higher diversity within the picoplankton size fraction compared to the nano- and microplankton. In multidimensional scaling analysis, community composition of all three size fractions correlated with cell size, silicate and phosphate, chlorophyll $a$ (chl $a$ ) and dinophysistoxin (DTX). Individually, each size fraction community composition also correlated with other different environmental parameters, i.e. temperature and nitrate. We observed a more homogeneous community of the picoplankton across all stations compared to the larger size classes, despite different prevailing environmental conditions of the sampling areas. This suggests that habitat niche occupation for larger-celled species may lead to higher functional trait plasticity expressed as an enhanced range of phenotypes, whereas smaller organisms may compensate for lower potential plasticity with higher diversity. The presence of recently identified toxigenic harmful algal bloom (HAB) species (such as Alexandrium fundyense and $A$. ostenfeldii) in the area points out the potential risk for this vulnerable ecosystem in a changing world.
\end{abstract}

\section{Introduction}

Marine planktonic microorganisms are key players in global primary production, dominating their habitats in terms of abundance and biomass (Zinger et al., 2012) and are, thus, important biological drivers in marine ecosystems (Falkowski et al., 1998; Field, 1998). The eukaryotic microalgal group comprises a large and diverse species complement and is responsible for sustaining major biogeochemical processes and ecosystem functioning. The relationship between species diversity and ecosystem functioning has appeared as a central issue during the last few decades (Loreau et al., 2001; Ptacnik et al., 2008), but the critical issues remain unresolved. Ultimately, high functional diversity is considered to represent an ecosystem that is less susceptible to changes and environmental stress (Loreau et al., 2001). Enhanced diversity may have a positive effect on ecosystem stability (Striebel et al., 2009) but need not be the driver of this interplay. Rather, the

\footnotetext{
* Corresponding author.

E-mail address: stephanie.westphal@awi.de (S. Elferink).
} 
stability of the ecosystem depends on the ability of communities to sustain species and functional groups, which are capable of differential responses to a changing environment (Isbell et al., 2011; Loreau et al., 2001). Under homogeneous environmental conditions, a minimal number of essential species may serve to maintain ecosystem stability, whereas a larger number is probably required for stability in a rapidly changing environment (Loreau et al., 2001). Furthermore, stable environments, such as oligotrophic and tropical oceans, and to a certain degree polar seas, lead to reduced adaptive capability of species, because their reaction norms in terms of phenotypic plasticity have narrow windows (Pachauri et al., 2014; Poulin et al., 2011; Thomas et al., 2012; von Dassow et al., 2015).

Expected anthropocenic environmental change is especially profound in the Arctic (Stocker, 2014; White, 1990) and thus has led to an increased number of scientific studies in this polar region during the last decade (Kilias et al., 2014a; Lovejoy et al., 2002; Madsen et al., 2001; Pančić et al., 2015; Thoisen et al., 2015; Włodarska-Kowalczuk et al., 2012). In general, Arctic and subarctic coastal waters around Greenland, Iceland, Norway, and Svalbard are characterized by ice cover during winter, high water stratification, and periods of low light availability (Hanna et al., 2008; Krauss, 1995; Sha et al., 2014; Straneo and Cenedese, 2015; Swift and Aagaard, 1981). Glacial ice production and sea-ice coverage greatly influence the productivity and seasonal succession of the plankton community, which has been studied in detail in Disko Bay (West Greenland) (Hansen et al., 2012). The presence of sea-ice reduces underwater light levels and leads to light limitation for phytoplankton growth. The combination of sea-ice breakup and glacial melt within the water column results in a very productive phytoplankton spring bloom. This impacts secondary production in the bay and thus provides the basis for traditional artisanal and commercial fishing and hunting activities in the region (Hansen et al., 2012).

Disko Bay marine resources are important to the Greenland economy, comprising one of the most important fishing areas in Greenland, and from where natural seafood products, such as fish, shrimp, and mussels constitute ca. $90 \%$ of the total Greenlandic export (Nielsen, 2005). Disko Bay is situated at the southern extent of the sea ice-covered area during winter; since the $1990 \mathrm{~s}$, the bay region has experienced a decrease in ice cover concurrent with higher water temperatures. Given these rapid changes, the bay is particularly well situated for studying species diversity of microorganisms in response to climate change, i.e. temperature, salinity and nutrient regime. Changes in the composition of key species at the base of the food web may lead to a cascade of changes at higher trophic levels and also impact biochemical cycles (Hansen et al., 2012). Ultimately, it is crucial to reveal which species are best able to adapt to changing environmental conditions.

Previous research on phytoplankton community structure in Disko Bay has been focused on diatoms (Dünweber et al., 2010; Krawczyk et al., 2014; Sha et al., 2014) and their primary copepod grazer Calanus spp. (Juul-Pedersen et al., 2006; Levinsen et al., 2000; Madsen et al., 2001). The area is characterized by high abundance and diversity of diatom species, especially of the genera Chaetoceros, Fragilariopsis and Thalassiosira. The species distribution is closely related to hydrographic conditions, in particular to surface water temperature and changing ice cover (Hansen et al., 2003; Hasle et al., 1996); in this context glacial melting are expected to alter salinity, stratification and nutrient regimes. However, little is known about molecular diversity and distribution of the eukaryotic marine phytoplankton in the Arctic, including the Disko Bay area of the Greenland coast. Furthermore, Arctic diversity surveys have only rarely investigated different sizefractions of the pelagic phytoplankton or subjected them to differential molecular analysis.

Recent developments in high-throughput next generation sequencing (NGS) technologies and their application in molecular microbial ecology have revealed a high diversity of eukaryotic lineages, many components of which escape detection by microscopic analysis and which comprise taxa that are difficult to isolate (Vaulot et al., 2008; Zinger et al., 2012). Sequencing ribosomal RNA genes (rRNA) has been integrated as a standard in studies to assess diversity of microorganisms from different environments and target groups (Bik et al., 2012; Gottschling et al., 2012; Medlin and Kooistra, 2010). Amplicon sequencing via NGS allows DNA barcoding approaches for marine phytoplankton (i.e., molecular markers for species/biodiversity assessment) and provides new insights into biodiversity of all planktonic sizefractions (De Vargas et al., 2015; Meyer et al., 2007; Taberlet et al., 2012). In line with the increasing use of NGS technologies, the amount of comparative data (i.e., taxonomically relevant sequence information) has increased exponentially. A high complexity of microbial eukaryotic communities has been revealed, comprising substantially more molecular operational taxonomic units (OTUs), when compared to data sets generated from strain-dependent and Sanger sequencing methodologies (Bittner et al., 2013; Egge et al., 2014; López-García et al., 2001; Moon-van der Staay et al., 2001; Vargas et al., 2015).

Our overall aim was to access the molecular biodiversity of three planktonic size-fractions in the coastal waters off west Greenland, with particular emphasis on microplankton $(20-50 \mu \mathrm{m})$, nanoplankton (3$20 \mu \mathrm{m})$ and picoplankton $(0.2-3 \mu \mathrm{m})$. This size segregation was invoked to investigate the potential impact of cell size on diversity because cell size is a prime parameter for many physiological and metabolic processes (e.g., larger cells of the microplankton are more morphologically plastic and have a lower cell surface to volume ratio as compared to nano- and picoplankton). Within this context, we also investigated which key environmental parameters may be associated with the observed diversity, particularly with respect to the presence of harmful algal bloom (HAB) species, because they possess a potential risk for ecosystem services and function in a changing environment.

\section{Materials and methods}

\subsection{Sampling}

Sampling was performed during the MSM-21/3 expedition (ARCHEMHAB; http://dx.doi.org/10.1594/PANGAEA. 819731) aboard the $R V$ Maria S. Merian at the western coast of Greenland (Uummannaq Fjord, Vaigat Strait and Disko Bay) between July 29 to August 8, 2012 (Fig. 1). Water samples were collected in the epipelagic zone by Niskin bottles mounted on a rosette-sampler with conductivity, temperature and depth (CTD) sensors to measure temperature and salinity (Holinde and Zielinski, 2015). In total, 15 stations were sampled at the surface layer (over the upper $30 \mathrm{~m}$ ) and, additionally, bottom water ( $10 \mathrm{~m}$ above ocean floor) was collected at eight stations.

Samples for nutrient measurements (nitrate, nitrite, ammonium, phosphate and silicate) were directly taken from the Niskin bottles at seven depths per station, processed without filtration and stored frozen at $-20^{\circ} \mathrm{C}$ for approximately a month until analysis. Nutrient samples were analyzed with a continuous-flow autoanalyzer (Evolution III, Alliance instruments, Frepillon, France) according to standard seawater methods. Determination of nitrate and nitrite followed the method of Armstrong et al. (1967), ammonium was determined according to Koroleff (1969), silicate according to Grasshoff et al. (1983), and phosphate according to Eberlein and Kattner (2000).

In situ chl $a$ concentrations were determined by filtering $1.0-2.0 \mathrm{~L}$ of seawater (GF/F glass microfiber filters, Whatman, UK; nominal pore size: $0.7 \mu \mathrm{m})$. The filtration unit was covered to exclude light, and sample filters were frozen immediately at $-80^{\circ} \mathrm{C}$ until laboratory analysis. Pigments were extracted by sonication of filters in $10 \mathrm{~mL}$ $90 \%$ acetone-water and incubation overnight at $4{ }^{\circ} \mathrm{C}$. The extract was centrifuged at $3020 \times g$ for $10 \mathrm{~min}$, and the fluorescence of the supernatant was determined at $665 \mathrm{~nm}$ (Laboratory Fluorometer TD-700, Turner Design, USA). Chl $a$ data are archived in PANGAEA (http://dx. 


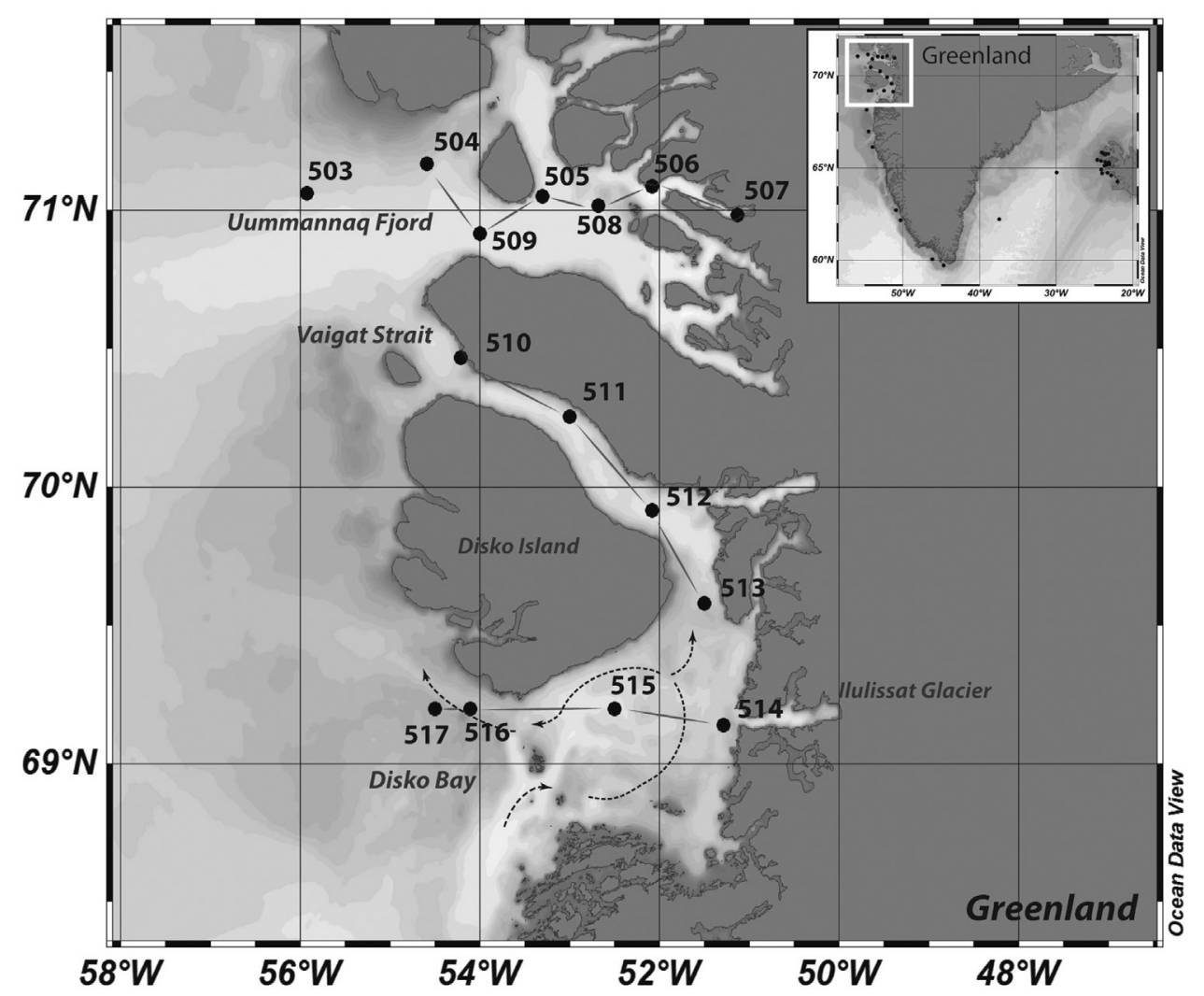

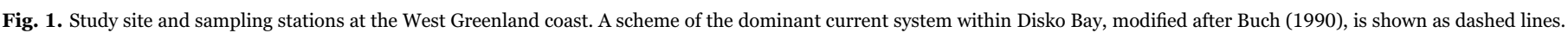
Stations belonging to one of the three observational transects in Uummannaq Fjord, Vaigat Strait and Disko Bay are connected with solid lines.

\section{doi.org/10.1594/PANGAEA.810651, Zielinski et al., 2013).}

Seawater for DNA extraction and toxin analyses was sampled integratively from the surface $(1-30 \mathrm{~m})$ with a membrane pump (QBY-25- SS; AGB-Pumpen, Germany). In total, 60 L of sea water per sampling station was passed over a sequential filter tower with different nylon mesh sizes $(200,50$ and $20 \mu \mathrm{m})$ to obtain different plankton size- fractions. Additionally, vertical net tows $(20 \mu \mathrm{m}$ mesh size, $50 \mathrm{~cm}$ net diameter) were performed from $30 \mathrm{~m}$ depth to surface. Plankton particulates $>20 \mu \mathrm{m}$ were subsequently size-fractionated using a filter tower as described above. For nano- and picoplankton size-fractions, $15 \mathrm{~L}$ water from three depths $(30,15$ and $3 \mathrm{~m}$ ) was collected with Niskin bottles. Water samples were first pre-filtered $(20 \mu \mathrm{m})$ and then $1 \mathrm{~L}$ of this filtrate was further sequentially sizefractionated by filtration over $3 \mu \mathrm{m}$ - and $0.2 \mu \mathrm{m}$-cutoff polycarbonate membrane filters (Millipore, USA).

Retentates from the filter tower and membrane filters for molecular analyses were backward-rinsed into centrifugation tubes with $0.2 \mu \mathrm{m}$ filtered seawater, adjusted with filtered seawater to a total volume of $45 \mathrm{~mL}$ and split into three $15 \mathrm{~mL}$ aliquots. Cell pellet aliquots were separated for DNA and hydrophilic and lipophilic toxin analysis. Pellets for DNA analysis were resuspended in $400 \mu \mathrm{L}$ AP1 buffer (Qiagen, Germany), transferred to a vial with $0.2 \mu$ m glass beads, shock frozen in liquid nitrogen and kept at $-20^{\circ} \mathrm{C}$ until further processing.

\subsection{Determination of phycotoxins in plankton samples}

Pellets for determination of hydrophilic paralytic shellfish poisoning (PSP) toxins were homogenized and extracted by reciprocal shaking with $0.03 \mathrm{M}$ aqueous acetic acid followed by centrifugation and filtration of the supernatant prior to analysis, as described in detail in Suikkanen et al. (2013). The PSP toxins were analyzed by ion-pair chromatography on a reverse-phase column coupled to post-column derivatization and fluorescence detection, according to Suikkanen et al.
(2013).

Pellets for determination of lipophilic phycotoxins were treated the same way as for the PSP toxins, but with $100 \%$ methanol as extraction solvent. Concentrations of lipophilic toxins, plus the hydrophilic domoic acid (DA), were determined by liquid chromatography coupled to tandem mass spectrometry (LC-MS/MS). Toxins analyzed included domoic acid (DA), gymnodimine (GYM), spirolides (SPX), dinophysistoxins (DTX) including okadaic acid (OA), pectenotoxins (PTX), yessotoxins (YTX) and azaspiracids (AZA). Methodological details of extraction and LC-MS/MS analyses are given in Krock et al. (2008).

\subsection{DNA Extraction, amplification and sequencing}

For the micro- $(20-50 \mu \mathrm{m})$ and nanoplankton $(3-20 \mu \mathrm{m})$ fractions, DNA extraction was performed with the Qiagen DNeasy Plant Kit (Qiagen, Germany). Picoplanktonic DNA was extracted using the Genomic DNA from Soil kit (Macherey-Nagel, Germany). The manufacturer's protocol was followed for both extraction methods. Genomic DNA was eluted from the column, and extracts were stored at $-20^{\circ} \mathrm{C}$.

Amplification for subsequent 454-sequencing (micro- and nanoplankton) was carried out in triplicate, targeting the hypervariable LSU D1/D2 region with the primer set Dir-F (5'-ACC CGC TGA ATT TAA GCA TA-3') and Dir2-CR (5'-CCT TGG TCC GTG TTT CAA GA-3') (Scholin et al., 1994). Adaptor sequences were added to the primers to be suitable for the 454-sequencing protocol (Roche). Details in PCR reactions, purification and quality control of amplicons are found in the Supplementary information.

For subsequent 454-pyrosequencing, equal molecular weights of the amplicons were pooled. The pooled amplicons were sequenced on a GS Junior sequencing platform (Roche, Germany).

The picoplankton $(0.2-3 \mu \mathrm{m})$ sample preparation differed slightly from the methods described above. The same primer set (Dir-F/ Dir2CR) was used, but the method was modified according to the require- 
ment for GS FLX 454-pyrosequencing. Amplification was done in triplicate and pooled amplicons were sequenced on a 454 GS FLX sequencer (Roche, Germany).

\subsection{Sequence read analysis}

In total 35 surface samples across size-fractions and eight bottom water samples were analyzed by 454-pyrosequencing. An analysis pipeline developed in-house (Stecher et al., 2015), for which the backbone consists of scripts from QIIME version 1.8 (Caporaso et al., 2010), was used for sequence-quality filtering and trimming, OTU clustering, chimera detection and preliminary taxonomic classification based on only-sequence-similarity characteristics. The OTUs thereby annotated as alveolates or stramenopiles were classified more accurately by PhyloAssigner version 6.166 (Vergin et al., 2013) with a phylogenetic placement onto reference trees based on $18 \mathrm{~S} / 28 \mathrm{~S}$ concatenated alignments.

Detailed information on reference sequences and tree sets, the quality control of the sequences and OTU clustering are found in the Supplementary information.

The final OTU table was built after removing singletons and doubletons (i.e., OTUs with only one or two reads, respectively, in the dataset) before further analysis, as recommended for spatial differentiation in species diversity, analysis of family or generic category (representing ecotypes or functional groups) (Terlizzi et al., 2009). If there was no match for generic category, the next higher nodal point of the phylogenetic tree with a match was selected for statistical analysis.

\subsection{Determination and discrimination of potential $H A B$ species}

Potentially harmful algal species were identified among classified OTUs. For more detailed species discrimination, qPCR assays were applied for some Alexandrium species, with nomenclature according to John et al. (2015). Primers and probes specific for A. fundyense, $A$. mediterraneum, A. minutum, A. tamarense, and A. tamutum (Toebe et al., 2013a), as well as $A$. ostenfeldii and $A$. pacificum (Table S1), were accessed for the qPCR assays. All qPCR reactions (1 ng DNA per reaction) were performed in triplicate in a $20 \mu \mathrm{L}$ assay on a StepOnePlus Real Time PCR System (Applied Biosystems, USA). Quantification was performed as described in Toebe et al., (2013a, 2013b), where efficiency and sensitivity were normalized from standard curves from cultured strains (DNA/cell) and diluted field plankton samples to account for potential matrix influences. Results were normalized to $1 \mathrm{~L}$, corresponding to filtered pump/net tow samples.

\subsection{Statistical analysis}

Statistical analyses were run in the R environment version 3.0.2 ( $R$ Development Core Team, 2011) with the package 'vegan' (Oksanen et al., 2013) and 'plyr' (Wickham, 2015). The sequence numbers per sample were not subsampled to the smallest sequence number of any sample, to avoid an increase of potential false positives (McMurdie and Holmes, 2014) by comparison to the relative abundance of counts in samples.

Rarefaction and species (OTU) accumulation curves of each station were calculated in vegan using the function 'rarecurve' and created after quality control and clustering to represent the local species richness and to serve as a reference for the covered diversity in a sample. Sample diversity was estimated by the inverse Simpson's index with the function 'diversity'. The Pielou's evenness index was additionally calculated to differentiate between environments inhabited by an equal number of different species or by a few dominant species. Estimation of sample diversity, taking only species richness or evenness into account, may be highly biased by the sequencing effort. The use of diversity indices, which account for species richness (number of
OTUs/taxa), evenness (relative abundance of sequences within OTU/ taxa) and total amount of sequences provide a relatively simple univariate statistic (Countway et al., 2010). The inverse Simpson's index, which was used here, is the reciprocal form of the Simpson's index, is sensitive towards dominant species and can range from 1 to the maximum number of OTUs in each sample and thus increases with increasing diversity (Magurran, 2004).

Non-metric multidimensional scaling (NMDS) with calculated Bray-Curtis dissimilarities was carried out to compare similarities among samples. The OTU table was Hellinger-transformed (double square-root transformation) as recommended for clustering or ordination of species abundance data (Legendre and Gallagher, 2001; Rao, 1995) with the 'decostand' function. Environmental factors were Hellinger-transformed to normalize the dataset and standardized by the factors' total abundance.

\section{Results}

\subsection{Physical environment and nutrient regime}

The upper $10 \mathrm{~m}$ of water column in Uummannaq Fjord was characterized by low salinity and showed the lowest salinity $(\sim 30)$ and lowest temperature $\left(\sim 3^{\circ} \mathrm{C}\right)$ within the Uummannaq Fjord transect towards the head of the fjord, close to the Perlerfiup Sermia Glacier (Station 507) (Fig. 2). Stations 504 and 510 are $88 \mathrm{~km}$ distant and connected the sampling areas within Uummannaq Fjord and Vaigat Strait. These latter stations exhibited similar salinities, but a temperature difference of $5{ }^{\circ} \mathrm{C}$, with lower temperature at Station $510\left(\sim 3^{\circ} \mathrm{C}\right)$. Temperature profiles of the Vaigat Strait indicated considerably colder surface waters than those of Disko Bay. Station 514, near the Ilulissat/Jacobshavn Glacier separating Vaigat Strait and Disko Bay, had the lowest temperature $\left(\sim 0^{\circ} \mathrm{C}\right)$ and highest salinity $(\sim 33.5)$ in surface water along the whole transect. In contrast, the highest temperature $\left(10^{\circ} \mathrm{C}\right)$ and lowest salinity $(\sim 30)$ were measured $50 \mathrm{~km}$ away in Disko Bay at Station 515. The more off-shore Stations 516 and 517 were characterized by warmer water $\left(\sim 7^{\circ} \mathrm{C}\right)$ with a high salinity ( 33$)$.

In the surface layer (integrated over 3-30 m), low nitrite, phosphate and ammonium concentrations $(\sim 0.02-1.1 \mu \mathrm{M})$ were measured at all stations (Fig. 3). Nitrate and silicate concentrations were highest towards the head of the fjord (Stations 506 and $507 ; \sim 3-9 \mu \mathrm{M}$ ) and close to the Ilulissat Glacier (Stations 513 and $514 ; \sim 9-12 \mu \mathrm{M}$ ). Chl $a$ concentrations, also integrated over $3-30 \mathrm{~m}$ ) at the 15 stations were lower within Uummannaq Fjord and along the Disko Bay transect (0.03-1.09 $\left.\mu \mathrm{g} \mathrm{L}^{-1}\right)$ compared to within Vaigat Strait (1.1-10.1 $\left.\mu \mathrm{g} \mathrm{L}^{-1}\right)$ (Fig. 4).

\subsection{Molecular biodiversity}

Clustering of 14 stations yielded OTU numbers that often correlated with sequencing depth (read numbers or amount of sequences per sample), showing more definable OTUs at stations with higher read numbers (total sequence counts) and vice versa. Rarefaction curves calculated to elucidate the grade of sequence saturation for each sample, revealed near-saturation for most samples with the exception of the picoplankton (Fig. S1).

Sequencing of three size-fractions resulted in a wide spectrum of sequencing depth and number of OTUs (4032-37,060 sequences; $110-$ 1165 OTUs, Table S2), after quality control via QIIME, i.e., removal of singletons, doubletons and potential fungal sequences (defined by QIIME). Among the total of 2759 OTUs, some OTUs overlapped between size-classes (Fig. 5). Most OTUs were shared between all three size-fractions (976), followed by shared OTUs between the nanoand picoplankton (419). The number of unique OTUs was greatest for the picoplankton (723), followed by the microplankton (97) and then nanoplankton (80). 


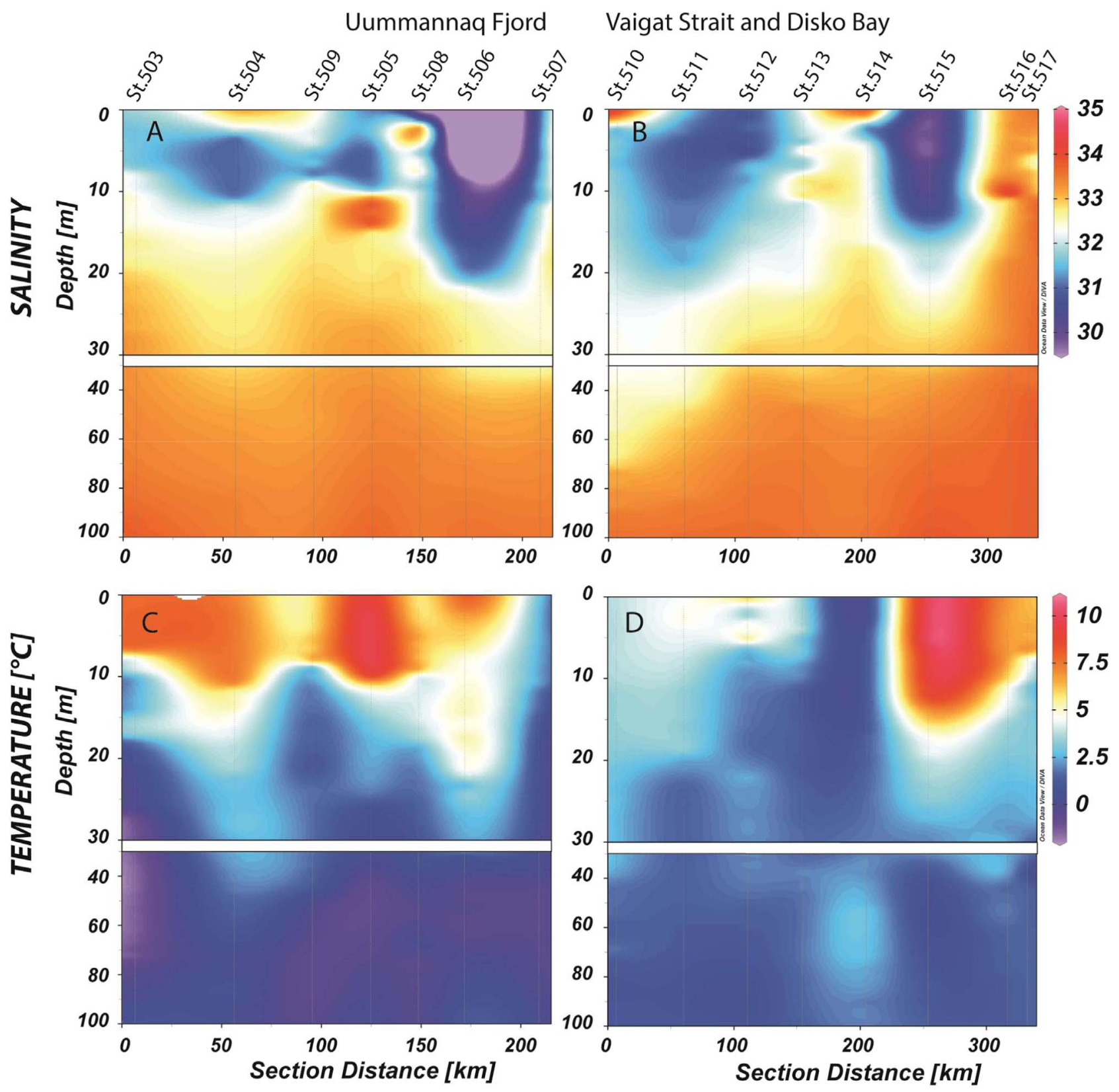

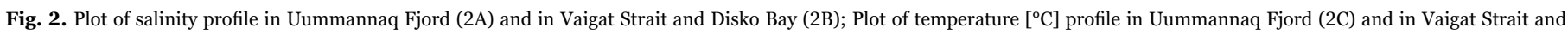
Disko Bay (2D). Plots show the upper $100 \mathrm{~m}$ water column of the sampling transects. Note the changes of the depth scale.

Univariate statistics derived as the inverse Simpson's diversity and Pielou's evenness indices were compared among the three areas and among the size-fractions and are shown as boxplots (Fig. 6 and Table S3). For the microplankton, median diversity indices (Fig. 6A) of the samples from Vaigat Strait and Disko Bay were significantly lower $(t-$ test: $p \leq 0.05$, Table $S 4$ ) than the median of the samples from the Uummannaq Fjord. The same applies for the nanoplankton ( $t$-test: $p \leq 0.05)$. Both larger size-fractions were significantly less diverse than the picoplankton ( $t$-test: $p \leq 0.05$ ), which showed similar median diversity for all three areas. The same relationships were observed for the median evenness of samples (Fig. 6B and Table S3). For the Vaigat Strait, where the highest chl a concentrations were found (Fig. 4), the overall lowest median diversity index (microplankton: 2.53; nanoplankton: 3.35) and evenness index (microplankton: 0.37; nanoplankton: 0.44 ) values were calculated. In contrast, in this region, the highest median diversity (10.02) and evenness (0.66) values were found for the picoplankton.
Similarity estimates among samples based on a Bray-Curtis dissimilarity matrix are presented in NMDS plots (Fig. 7) for the three size-fractions. The NMDS plot (Fig. 7A) revealed a separation of the three size-fractions with a higher overlap between the micro- and nanoplankton (ANOSIM statistics $R=0.6936$, significance $=0.001$ ). Similarities between size-fractions indicated a higher similarity within the picoplankton in all three areas (Uummannaq Fjord, Vaigat Strait and Disko Bay) (Fig. 7B). Fitting the environmental factors to the NMDS ordination resulted in significant ( $p \leq 0.05$, Table S5 and S6) linear correlations with ranked distances between the samples (p-fitting for cell size, chl $a$, DTX, silicate, and phosphate) (Fig. 7A). Different environmental parameters correlated significantly $(p \leq 0.05)$ to the NMDS ordinations of each size fraction (Fig. 7B). For the microplankton, temperature nitrate, phosphate and DTX correlated significantly $(p \leq 0.05)$, whereas for the nanoplankton the most significant associations were with temperature, nitrate, silicate, and the toxins SPX, DTX and PTX. For picoplankton, 


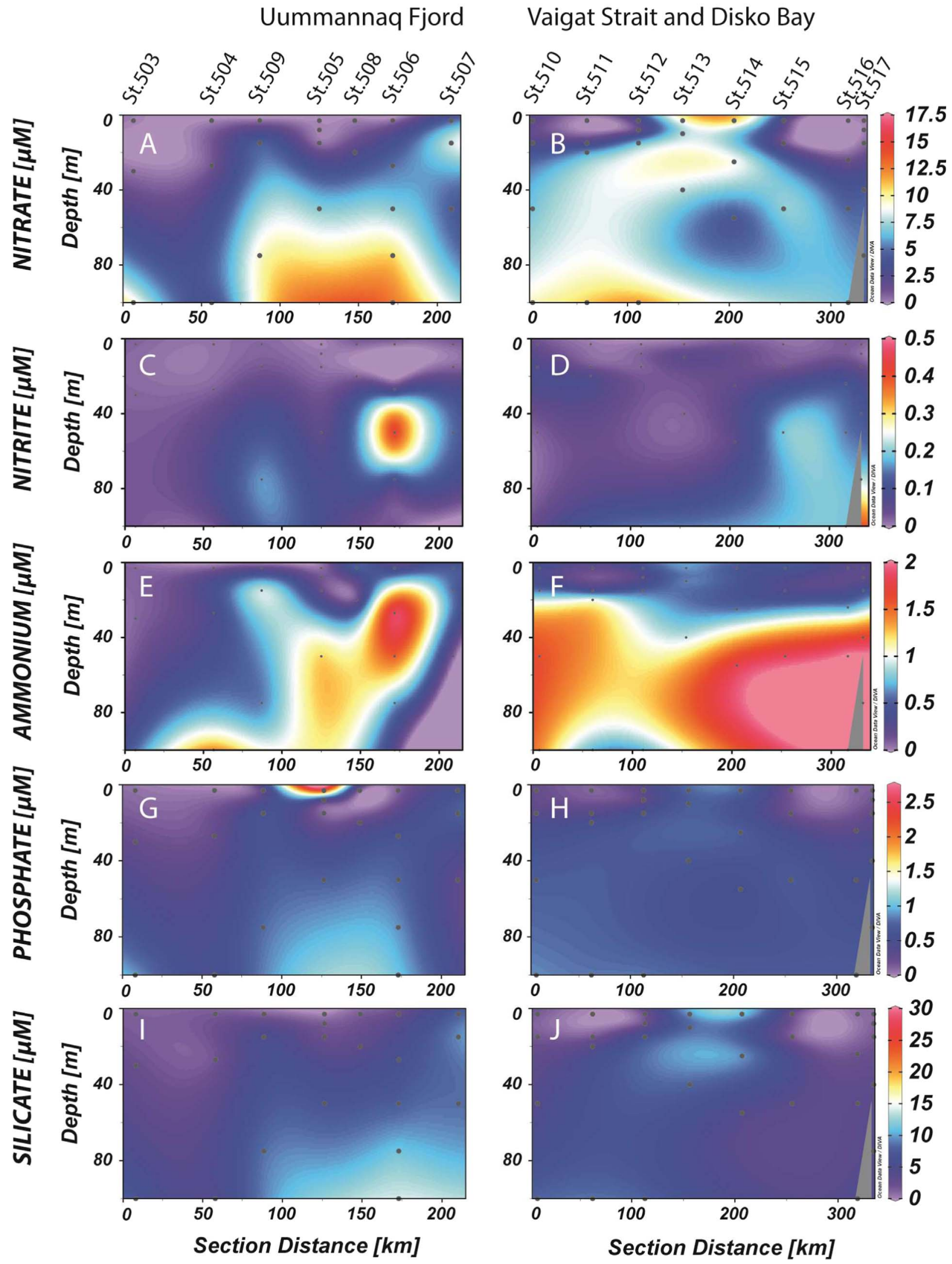

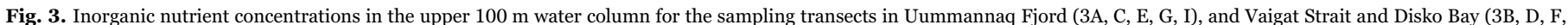
H, J). Plots show profile of nitrate $[\mu \mathrm{M}](3 \mathrm{~A}-\mathrm{B})$, nitrite $[\mu \mathrm{M}](3 \mathrm{C}-\mathrm{D})$, ammonium $[\mu \mathrm{M}](3 \mathrm{E}, \mathrm{F})$, phosphate $[\mu \mathrm{M}](3 \mathrm{G}, \mathrm{H})$, and silicate $[\mu \mathrm{M}](3 \mathrm{I}-\mathrm{J})$.

the salinity, nitrate, phosphate, silicate, chl $a$ and DTX variables were dominant. Thus, nitrate and DTX were the only environmental parameters that correlated significantly $(p \leq 0.05)$ to the
NMDS ordinations for all size-fractions. Nitrite, ammonium, PSP toxins and DA did not correlate significantly for any NMDS ordination. 

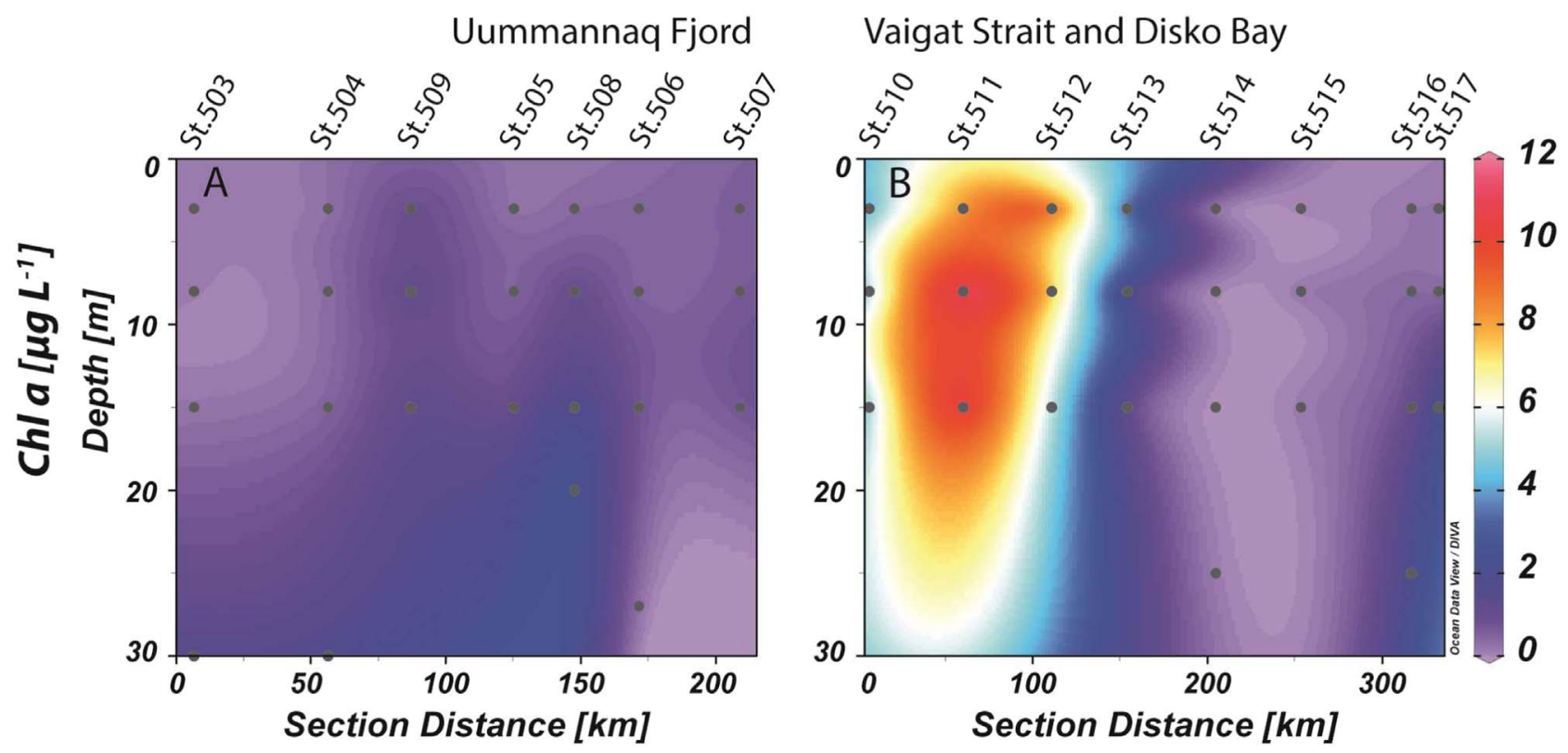

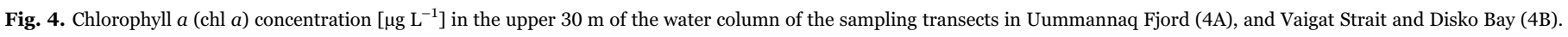

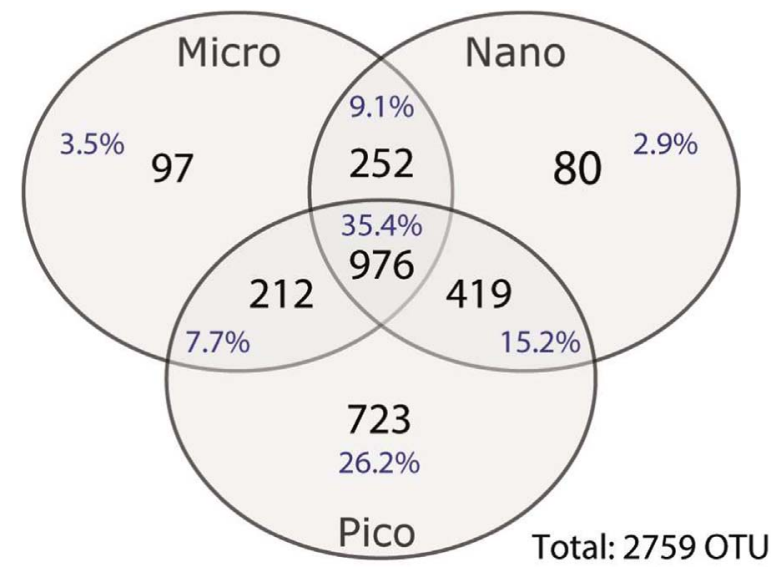

Fig. 5. Venn diagram of OTU intersections between the three different size-classes (microplankton: $20-50 \mu \mathrm{m}$, nanoplankton: $3-20 \mu \mathrm{m}$ and picoplankton $0.2-3 \mu \mathrm{m}$ ). Numbers represent the number of OTUs with their corresponding percentage [\% of total OTU]. OTUs were generated based upon a similarity threshold of $98 \%$.

The relative abundances of different OTUs were grouped accordingly to their affiliations to major phylogenetic groups pre-classified by QIIME (e.g., as Alveolata, Haptophyta, Metazoa and Stramenopila) for each size-fraction (Fig. 8 and Table S7). For all three size-fractions, the dominant groups were stramenopiles and alveolates, covering $83.4 \%$ of total community richness. Other groups, comprising $11.7 \%$, and $5.0 \%$ of the reads, respectively, either could not be assigned to particular groups or were non-specifically assigned to eukaryotes. The majority of the OTUs could thus be assigned at least to a phylum.

The Dinophyceae alignment, consisting of 640 sequences, was $5748 \mathrm{bp}$ long and comprised 3,518 parsimony informative sites (61\%; 5.50 per terminal taxon). Many nodes of the best fitted maximum likelihood $(\mathrm{mL})$ tree $(-\mathrm{ln}=218,591.63)$ showed high if not maximal support values, although the backbone exhibited many weakly supported nodes. Most Dinophyceae were retrieved as monophyletic (94LBS; LBS $=\mathrm{mL}$ bootstrap support) and segregated into a number of more or less established taxonomic units at the ordinal level, such as Dinophysiales (99LBS), Gonyaulacales, Peridiniales, Prorocentrales and Suessiales (80LBS), whereas other unarmored "Gymnodiniales" were polyphyletic.
The concatenated stramenopile alignment consisted of 1777 sequences and 9212 site columns. The underlying average sequence length was $2338 \mathrm{bp}$. The 5,817 sites of the 9212 columns were used for phylogenetic inference by RAxML (63\%, 3.37 per taxon). Most nodes close to the branch end showed good to maximal support values $(\geq 60)$, but many inner nodes were poorly supported. Most of the OTUs have been assigned at least to generic category (placements just below terminal node) and represent ecotypes or functional groups; this assignment is therefore not a major issue for our purposes.

Phylogenetic placement on reference trees for alveolates and stramenopiles yielded partial taxonomic assignment down to generic level. For alveolates, $78.7 \%$ of their pre-assigned OTUs were subsequently placed within a generic category, covering $78.8 \%$ of the richness within this group (Table 1). For stramenopiles, $75.0 \%$ of the OTUs were assigned to a genus, covering $84.9 \%$ of the richness in this group. The phylogenetic placement of stramenopile and alveolate OTUs on the reference trees resulted in an $82 \%$ OTU match for generic categories.

For the microplankton size-fraction $(20-50 \mu \mathrm{m})$, stramenopiles were the dominant group, especially in Vaigat Strait $(\geq 84 \%)$. Within the stramenopiles, most reads identified diatoms, with Chaetoceros followed by Thalassiosira and Skeletonema in abundance (http://dx. doi.org/10.1594/PANGAEA.857403). In the Uummannaq Fjord region, the relative read abundance of Skeletonema and Thalassiosira switched in comparison to Vaigat and Disko Bay. For Disko Bay, alveolates showed the highest relative abundance among the stations $(\geq 52 \%)$, with the dinoflagellates Protoperidinium (Peridiniales), Gyrodinium (phylogenetic position uncertain) and Biecheleria (Suessiales) predominant. For Uummannaq Fjord, we found no clear group distribution pattern, except for the high abundance of metazoans ( $74 \%$ and $84 \%$ ) at Stations 509 and 505, respectively, and more unassigned reads at the head of the fjord (Station 507; 19.4\%). In all other microplankton samples, metazoans and unassigned reads each accounted for $<5 \%$ of total abundance at each station.

Within the nanoplankton $(3-20 \mu \mathrm{m})$, we found a more even and similar distribution of alveolates among the three sampling areas $(39.3 \% \pm 19.8 \%)$, followed by stramenopiles $(49.4 \pm 20.2 \%)$. Stations $513-515$ showed different profiles, with $60-70 \%$ of the reads belonging to stramenopiles at Stations 513\% and 514\% and 90\% of the reads belonging to alveolates at Station 515. Compared to the microplankton, 

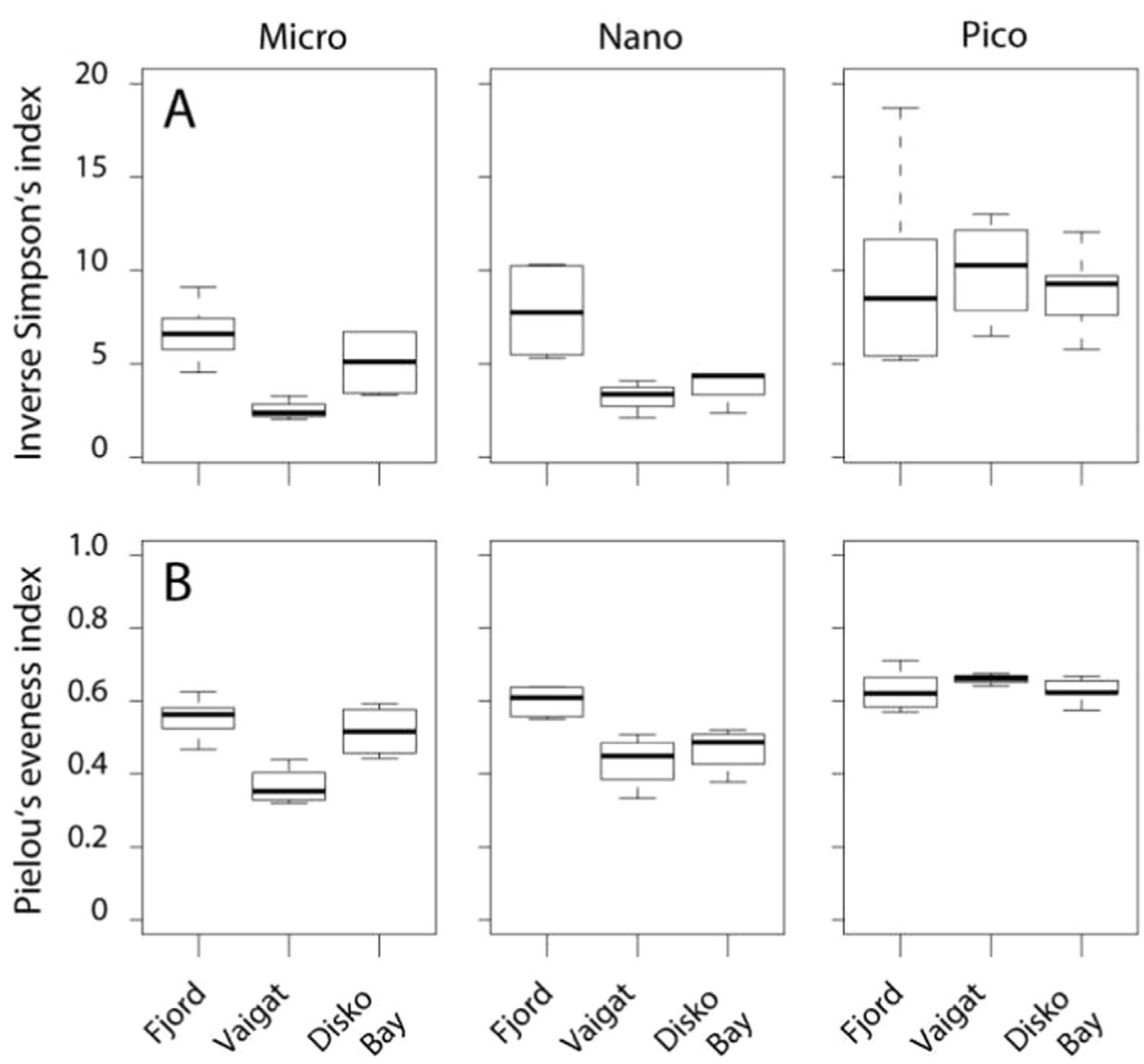

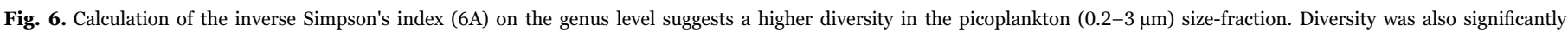

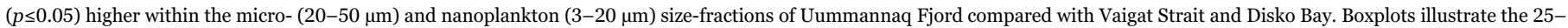

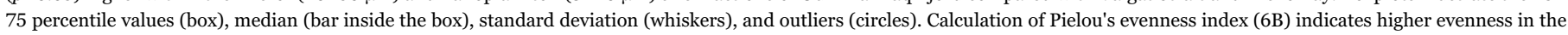
picoplankton and in Uummannaq Fjord.

we found fewer reads for the diatoms Chaetoceros and Thalassiosira, but more reads accounted for Skeletonema (http://dx.doi.org/10. 1594/PANGAEA.857403). The heterotrophic dinoflagellate Protoperidinium was less abundant in read number within the Vaigat region compared to the other stations. The dominant group at Station 504 was Metazoa (51\%; most of them belonging to Lophotrochozoa and Arthropoda). For all other nanoplankton stations, metazoans accounted for $<3 \%$ of reads.

Within and among the stations, the picoplankton $(0.2-3 \mu \mathrm{m})$ groups were more evenly distributed and showed less differences among samples compared to the micro- and nanoplankton. The main groups were alveolates (18-69\%), stramenopiles $(\leq 41 \%)$ and Viridiplantae $(\leq 41 \%)$. The alveolates contributed more to the community diversity at greater depth $(53.2 \% \pm 11.1 \%)$ than near the surface $(26.6 \% \pm 4.8 \%)$. Compared to the two larger size-fractions, a higher number of reads could not be assigned to generic category (picoplankton: $68.5 \%$, micro-/nanoplankton: $15.7 \% / 19.1 \%$ ), and $43.3 \%$ of the reads could only be assigned to kingdom or phylum level.

\subsection{Association of toxin derivatives with potential $H A B$ species}

Toxin profiles (Fig. 9) of plankton of the outer Uummannaq Fjord stations 503-509 most commonly included domoic acid (DA) and spirolides (SPX, each $\sim 50 \pm 27 \%$ relative toxin concentration), whereas the inner stations 505 - 507 comprised $~ 90 \%$ SPX and $10 \%$ pectenotoxins (PTX, Fig. 9 and Table S8). For the Vaigat Strait stations 510-513, SPX and dinophysistoxins (DTX) were predominant, with SPX concentration decreasing $\left(6 \mathrm{ng} \mathrm{NT}^{-1}\right.$ to $\left.0.23 \mathrm{ng} \mathrm{NT}^{-1}\right)$ and DTX abundance increasing $\left(0.11 \mathrm{ng} \mathrm{NT}^{-1}\right.$ to $\left.1.9 \mathrm{ng} \mathrm{NT}^{-1}\right)$ along the transect. At station 515 and 517 (Disko Bay), SPX dominated the toxin profiles (90-98\% relative toxin concentration). Paralytic shellfish poisoning (PSP) toxins were detected (423.6 ng NT ${ }^{-1}$ ) only at Station 516, where highest SPX concentration was also measured (61.0 ng NT ${ }^{-1}$ ).

With respect to the molecular diversity of potential HAB species, a low number of OTUs (maximum 373 OTUs per station per taxon) were assigned to Alexandrium, Dinophysis, Gonyaulax, Gymnodinium, Prorocentrum or Pseudo-nitzschia (Fig. 9 and Table S9), but these assignments did not apparently correlate well with toxin composition or concentration in plankton. At Station 516, 373 OTUs were assigned to species of Alexandrium, whose presence was also confirmed by microscopy (results not shown, see Tillmann et al., 2016). To differentiate toxic and non-toxic species of Alexandrium, qPCR assays were applied for three stations (515, 516 and 517). We detected the usually toxic $A$. fundyense (Group I) and A. ostenfeldii, as well as the non-toxic A. tamutum, but we found no signals for A. mediterraneum (Group II), A. tamarense (Group III), A. pacificum (Group IV) or A. minutum (Table 2).

\section{Discussion}

\subsection{Evaluation of the marker sequence approach to plankton diversity}

Plankton biodiversity analyses with an amplicon sequencing approach are typically based upon the V4 or V9 region of the SSU rRNA (De Vargas et al., 2015; Massana et al., 2015; Stoeck et al., 2010). We decided, however, to focus on the LSU rRNA D1/D2 region, because it 

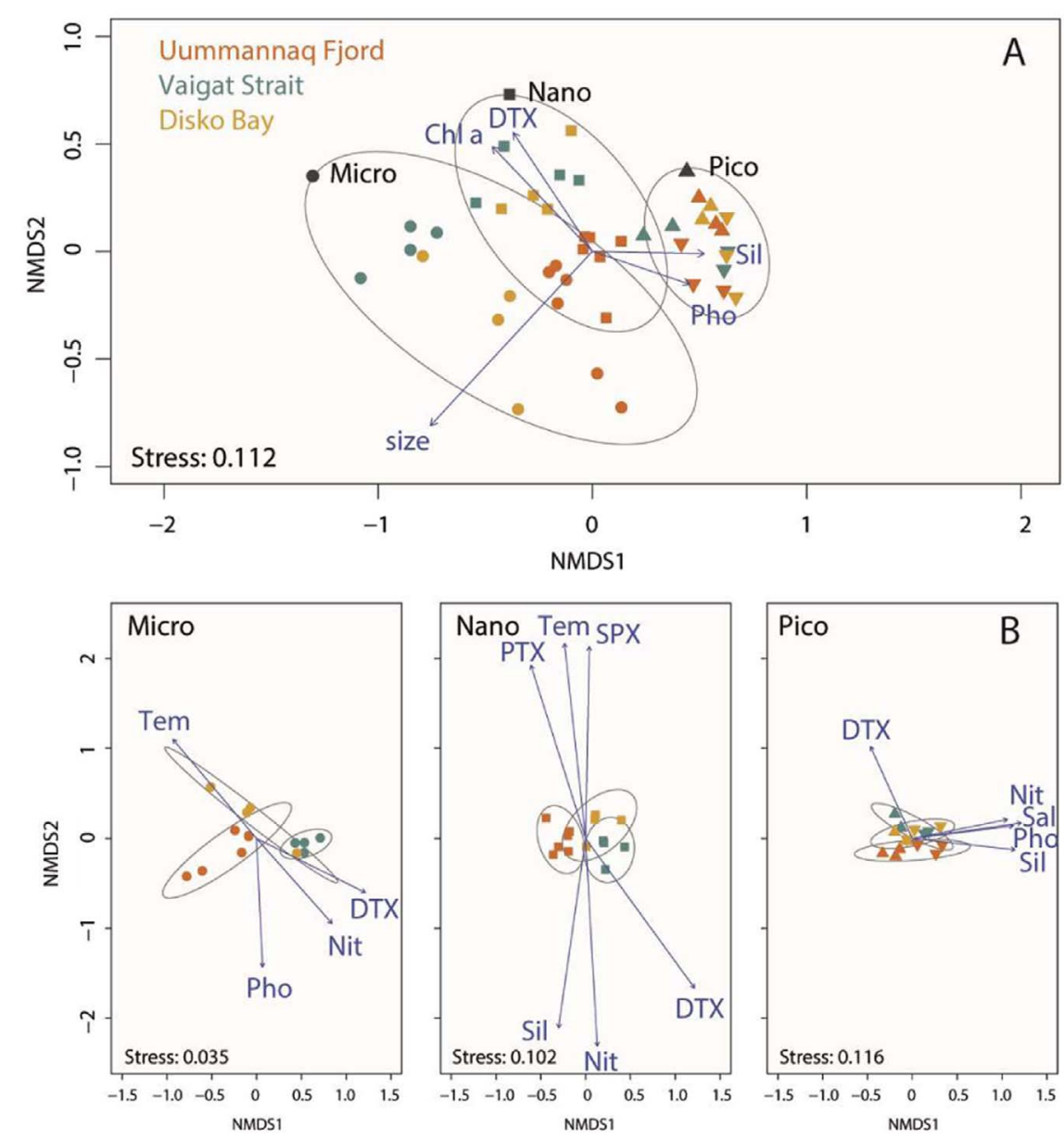

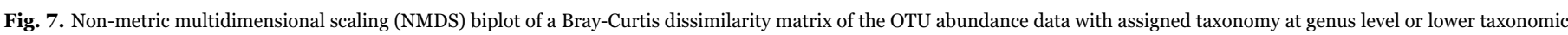

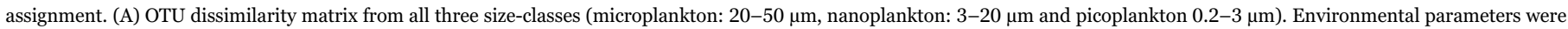

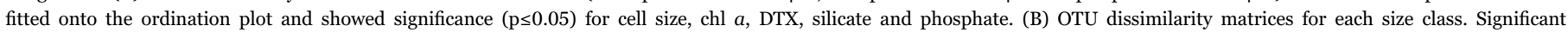

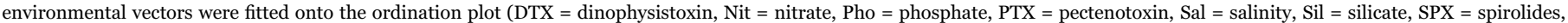

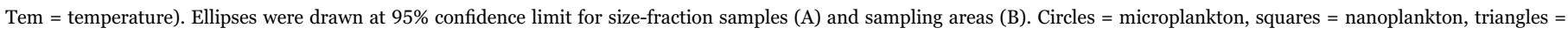
picoplankton samples; orange $=$ Uummannaq Fjord, green $=$ Vaigat Strait, yellow $=$ Disko Bay .

has been shown to have a higher resolution to differentiate at the species level for many protists, such as diatoms, dinophytes and haptophytes (John et al., 2003; Kretschmann et al., 2015; Medlin et al., 1998; Moniz and Kaczmarska, 2009; Sonnenberg et al., 2007; Toebe et al., 2013a). Some plankton groups (e.g., dinophytes) may be overrepresented compared to others as a consequence of group specific biases such as multiple rRNA copies in the genome and primer specifications (Huber et al., 2009; Kunin et al., 2010). The haptophytes and prasinophytes were rarely detected in our study. Underrepresentation of these groups, based upon sequencing with universal primers for rRNA, is a known problem, and thus specific primers targeting both groups have been used in recent studies (Bittner et al., 2013; McDonald et al., 2007). It is commonly accepted, however, that no ideal universal primer exists. New primers have been designed for the Illumina sequencing platform to minimize such biases for upcoming field investigations.

Methodological errors in 454-sequencing and OTU clustering are also known, and may lead to an over- or underestimation of diversity (Reeder and Knight, 2009). To counter this issue, we have first taxonomically assigned OTUs within QIIME to higher systematic categories. Second, we have been able to reliably assign OTUs to generic category down to genus or even species level, or to higher nodal points in the phylogenetic tree, by accessing PhyloAssigner, which contains the representative diversity of the SSU and LSU rRNA gene regions (http://dx.doi.org/10.1594/PANGAEA.857403). However, an
OTU must not necessarily directly translate to a unique species because within some species intraspecific variances of rRNA copies (ribotypes) have been reported. Several OTUs can therefore correspond to a single species (John et al., 2005; Kremp et al., 2014).

\subsection{Molecular biodiversity}

High-throughput sequencing has facilitated reliable environmental surveys of molecular diversity and is now commonly used to study marine plankton communities (De Vargas et al., 2015; Egge et al., 2013; Sogin et al., 2006; Stoeck et al., 2010). The approach is also possible because a tremendous effort has been made during the past decade to resolve alpha-taxonomy in protists and to link DNAsequences to species names. Otherwise, any DNA-barcoding approach is condemned to fail (Adl, 2013), although references to OTUs rather than species sensu stricto have been used (Schloss and Handelsman, 2005) to access species diversity of communities and thus make studies more comparable. Our comparison of micro-, nano-, and picoplankton reveals many OTUs belonging to more than one size-fraction. The range of a size-fraction to classify microorganisms into micro-, nano-, and picoplankton is largely operational and not based on objective criteria, and may therefore differ among studies (De Vargas et al., 2015; Massana et al., 2015). Our OTU overlap of $\sim 8-15 \%$ between size-fractions and $\sim 35 \%$ among all stations is somewhat higher than observed in other studies (Kilias et al., 2014b; Massana et al., 2015). 

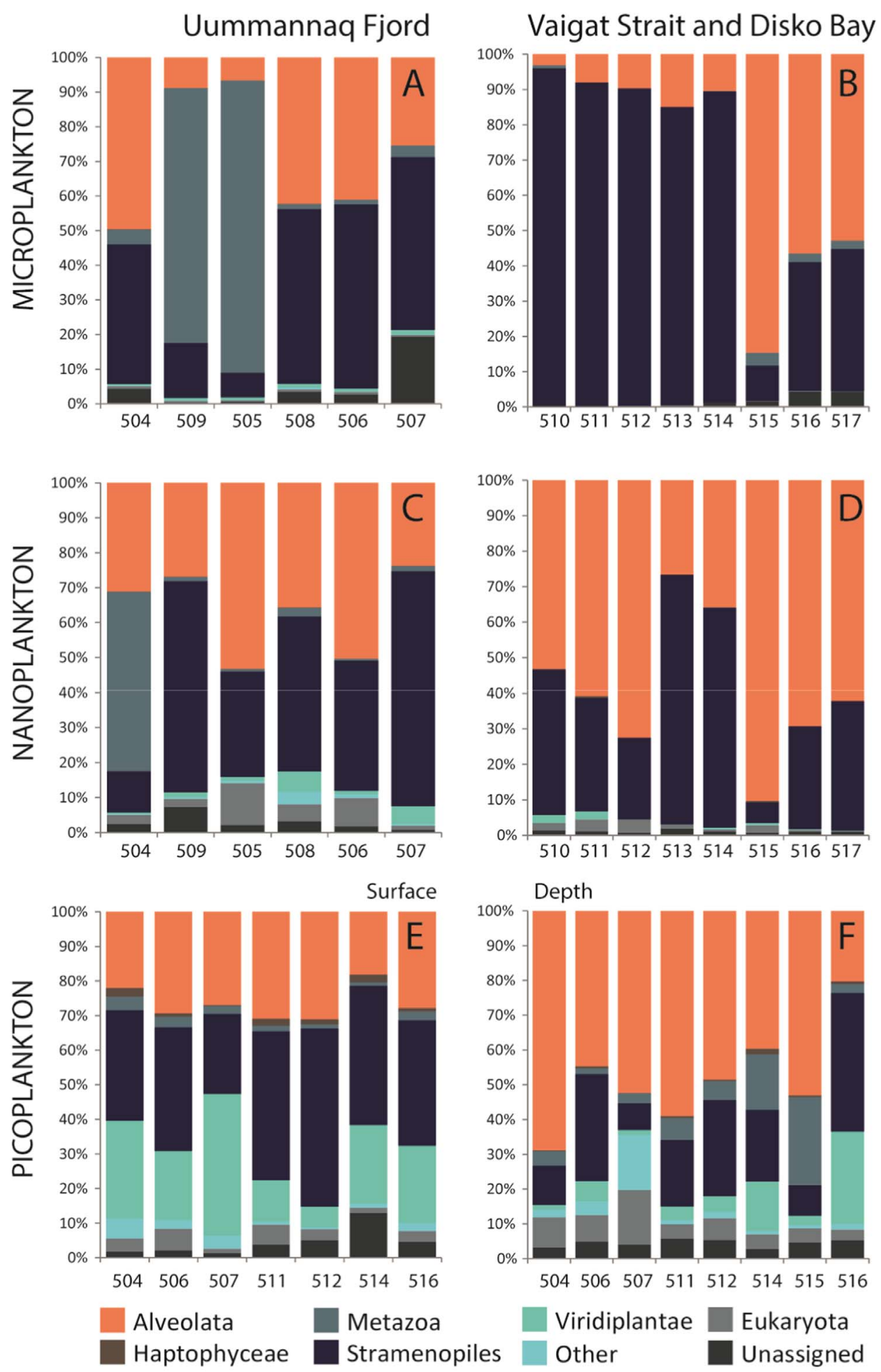

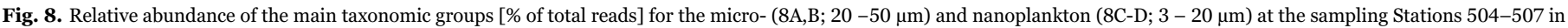

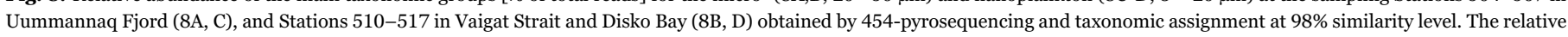

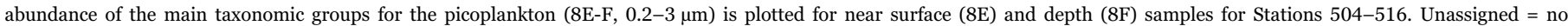

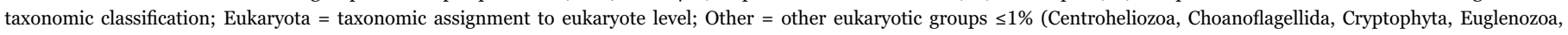
Glaucocystophyceae, Picozoa, Rhizaria).

Explanations may include differences in life history stages (e.g., small gametes or spores) and alternative cell forms, or the ability to form chains or colonies. Although low vacuum pressure was applied during sample fractionation and filtration to minimize cell breakage or disruption of cells in chains, some of the OTU overlap might constitute artifacts of such handling and thus may influence apparent diversity of each size class.

The high number of unique OTUs within the picoplankton and overall higher diversity as revealed by diversity statistics is in agreement with an overall higher diversity of small eukaryotes (De Vargas 
Table 1

Effectiveness of phylogenetic placement of OTUs on the reference tree of alveolates (A) and stramenopiles (B).

\begin{tabular}{llllll}
\hline Level & $\begin{array}{l}\text { Counts } \\
\text { in level }\end{array}$ & $\begin{array}{l}\text { Counts } \\
\text { in level } \\
\text { (\%) }\end{array}$ & $\begin{array}{l}\text { Sequence } \\
\text { abundance }\end{array}$ & $\begin{array}{l}\text { Sequence } \\
\text { abundance } \\
\text { (\%) }\end{array}$ \\
\hline A & Genus & 37 & 78.7 & 173,746 & 78.8 \\
& Family & 5 & 10.6 & 10,439 & 4.7 \\
& Order & 4 & 8.5 & 34,391 & 15.6 \\
Class & - & - & - & - \\
& Phylum & - & - & - & $\mathrm{v}$ \\
Alveolates & 1 & & 7,030 & 3.2 \\
B & Genus & 45 & 75 & 190,897 & 84.9 \\
& Family & 2 & 3.3 & 221 & 0.1 \\
& Order & 3 & 5 & 959 & 0.4 \\
Class & 7 & 11.6 & 17,526 & 7.8 \\
Phylum & 2 & 3.3 & 470 & 0.2 \\
Stramenopiles & 1 & & 14,719 & 6.6 \\
\hline
\end{tabular}

et al., 2015; López-García et al., 2001; Vaulot et al., 2008). Although we observed high sequence read numbers yielding the highest molecular biodiversity (OTUs) in picoplankton samples, we acknowledge that saturation may not have been achieved and thus the diversity may not have been fully resolved in all cases. Among the postulated total marine eukaryotic plankton diversity of $\sim 150,000$ OTUs, more than half may be represented by picoplankton (De Vargas et al., 2015). Explanations for the higher diversity may be a reflection of their smaller cell size. The small size of the picoplankton results in a higher surface to volume ratio, and therefore organisms of this fraction may possess and exhibit different metabolic processes and kinetic mechanisms (e.g., nutrient uptake, light utilization) compared to the nano- and microplankton (Litchman et al., 2007). Cell size may be seen as a master trait that shapes ecological niches of phytoplankton (Litchman and Klausmeier,
2008). For example, picoplankton often dominate low nutrient environments, whereas larger cells (e.g., of diatoms) tend to increase in abundance with increasing nutrients, partially because of their lower affinity but higher maximum uptake rates (Kerimoglu et al., 2012; Litchman et al., 2009; Smith et al., 2014). Additionally, small cell size obviously allows fewer morphological variants and this may account for a lower functional trait plasticity (i.e., a range of phenotypes), whereas larger-celled species may show a higher plasticity instead of evolving several different optimal phenotypes (Rengefors et al., 2015). Hence, higher species diversity of picoplankton compensates for potentially higher plasticity of the larger cell-size taxa. Taking the high diversity of the picoplankton community into account, different species may be more specialized and establish different ecological niches. Thus, the community of more specialized species might be able to adapt to a broader range of environmental conditions. The picoplankton community might also adapt faster compared to the microplankton because of the larger effective population size, standing genetic variation and shorter generation times.

\subsection{Potential linkage of diversity and biogeographical partitioning to environmental parameters}

The high spatial and temporal similarity in the environmental regime may reflect the fact that sampling stations were located within a radius of $250 \mathrm{~km}$ and were sampled synoptically within one week. Nevertheless, definable differences in diversity and biogeography of taxa distribution within size-fractions were evident from among the study areas.

In general, fjords are characterized by an environmental gradient with high freshwater input, often from glacial influence, yielding high stratification with sharp surface temperature gradients and lower salinity and high nutrient input at the head of the fjord, and open

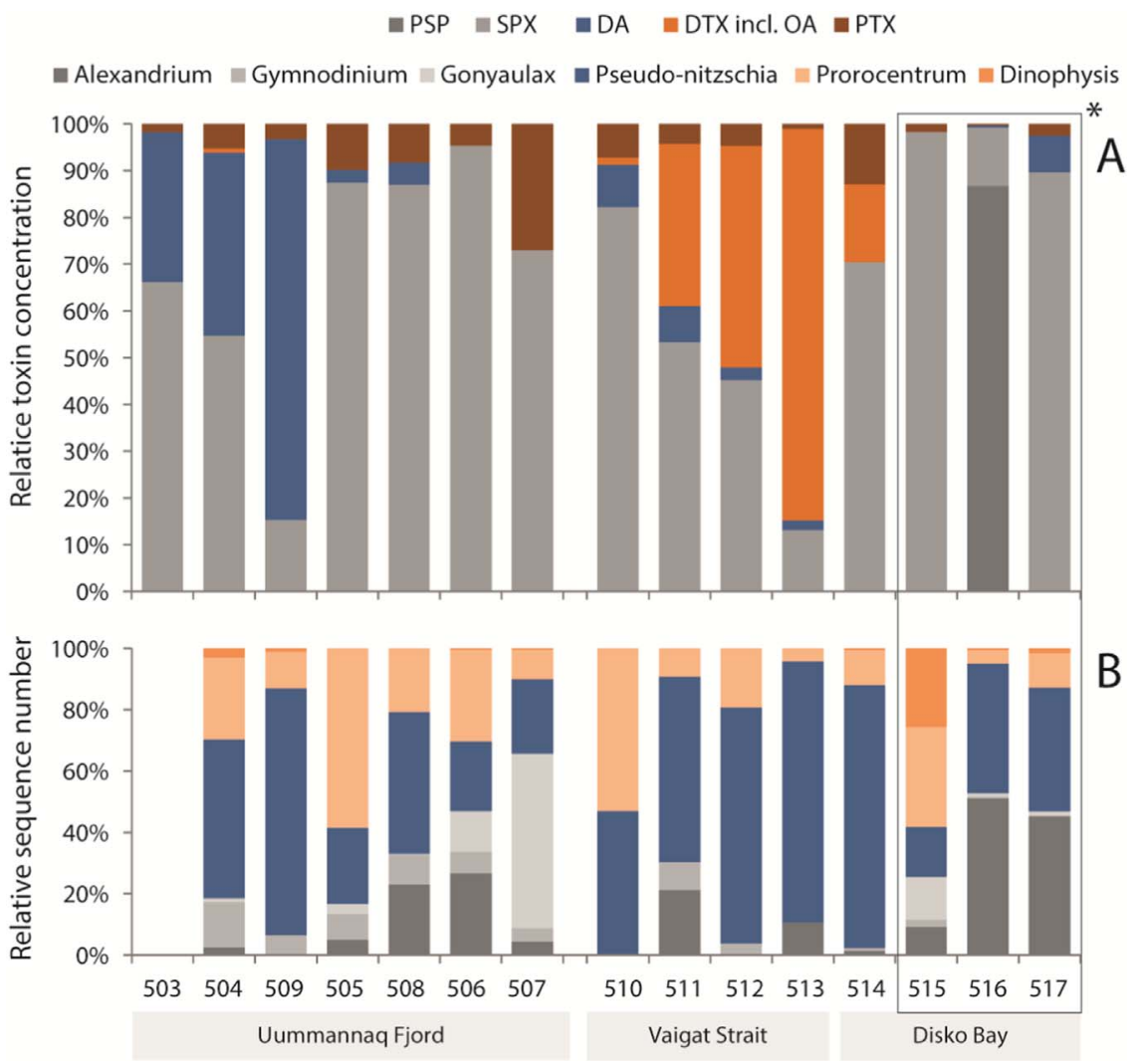

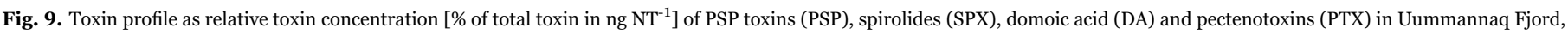

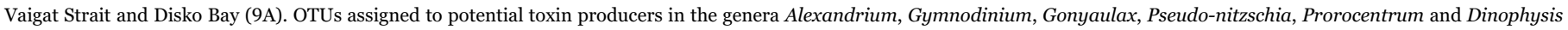
are presented as relative sequence number [\%] (9B). ( ${ }^{*}$ ) qPCR yielded positive signal for A. ostenfeldii, A. tamutum, and A. fundyense (Group I). 
Table 2

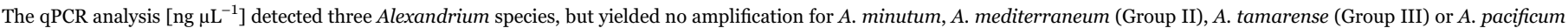
(Group IV); NT = Net Tow sample.

\begin{tabular}{|c|c|c|c|c|c|c|c|c|c|}
\hline \multirow[t]{2}{*}{ Station } & \multicolumn{3}{|c|}{ A.fundyense $^{\text {a }}$ (Group I) } & \multicolumn{3}{|c|}{ A. ostenfeldii ${ }^{\text {a }}$} & \multicolumn{3}{|c|}{ A. tamutum } \\
\hline & Nano & Micro Pump & Micro NT & Nano & Micro Pump & Micro NT & Nano 31.1 & Micro Pump & Micro NT \\
\hline 515 & - & 22.2 & 24.3 & - & 26.9 & 269.9 & 31.1 & 24.9 & 27.9 \\
\hline 516 & - & 27.7 & 28.0 & 31.6 & 23.5 & 21.5 & 31.9 & 24.4 & 27.0 \\
\hline 217 & - & 38.7 & - & 28.7 & 22.6 & 22.9 & - & 26.2 & 28.8 \\
\hline
\end{tabular}

${ }^{a}$ Indicates toxigenic species.

coastal ocean conditions (e.g., higher salinity, increased mixing) beyond the mouth of the fjord. This typical pattern was shown for the Uummannaq Fjord (Figs. 2 and 3). The persistence of this environmental gradient together with the different phytoplankton community might be the reason that no environmental vectors within the non-metric multidimensional scaling (NMDS) analysis could be clearly identified with these species assemblages. In any case, the environmental conditions associated with the surface water mass flowing towards the mouth of the fjord determined the structure of the micro- and nanoplankton community of the fjord and thereby yielded both higher molecular diversity and evenness compared to well-mixed plankton communities and water masses from Vaigat Strait and Disko Bay. Prevailing environmental conditions may shape the phytoplankton community to a certain degree and might allow a community to develop a higher diversity and evenness within a more hydrodynamically stable regime within the fjord and thereby contributing to increased biostability within the ecosystem. A higher molecular diversity and evenness was found for eukaryotic plankton within Uummannaq Fjord and particularly for the picoplankton, which suggests a more stable community capable to buffer responses to slightly changing environmental conditions. The picoplankton might buffer the different environmental conditions in spite of their lower morphological plasticity by means of higher surface/volume ratios for nutrient acquisition. The NMDS (Fig. 7A) suggests a positive influence of silicate and phosphate on picoplankton samples supporting their better capability of nutrient uptake.

The glacial ice-melt runoff from the Ilulissat Glacier results in up to $5{ }^{\circ} \mathrm{C}$ lower water temperature adjacent to the glacier. Local hydrodynamic factors and currents transport this cold glacial melt water into the Vaigat Strait (Fig. 1), also presumably advecting the plankton component and resulting in a different community profile (higher diatom OTU abundance) within the microplankton size-fraction in this area. The nutrient input by the upwelling in front of the glacier, and the contribution of silicate by runoff of melt water, may explain the high silicate concentrations at the surface. This interpretation also supports the link to potential growth of diatoms, which incorporate silicate into their cell walls. Unfortunately, we lack detailed information about the biomass for this data set, but high chl $a$ in the Vaigat Strait (Stations 510 - 513, Fig. 4), the depletion of nutrients, as well as the lower calculated diversity and evenness indices (Fig. 6) provide indirect evidence of higher phytoplankton biomass production.

On the molecular level, this corresponds to a high OTU abundance of diatoms within the microplankton, even though OTU abundance cannot be directly correlated to biomass. Nevertheless, the chl $a$ vector in the NMDS analysis pointing towards micro- and nanoplankton fractions of Vaigat Strait (Fig. 7A) does suggest a higher contribution to the biomass from the bigger cells. The higher number of unknown OTUs within the picoplankton may belong to heterotrophic taxa, which do not contribute to chl $a$. The higher nitrate concentrations at Stations 513 and 514 could also support continued cell growth and could explain the higher relative abundance of diatoms within the nanoplankton at these two stations.

The micro- and nanoplankton community within Disko Bay was defined by a higher temperature and lower nutrients (phosphate and nitrate; Fig. 7B). This might have had a positive effect on dinoflagellate abundance and thus would lead to a lower species diversity and associated lower evenness. Disko Bay represents an intersection of environmental influences from the outer coast, the adjacent fjord and glacial contribution and the Vaigat Strait, including advective processes and associated plankton communities.

There is an ongoing debate as to whether or not protists are truly cosmopolitan, and lack distinct distributions (Fenchel and Finlay, 2004), or also comprise endemic species (Medlin, 2007). In our study, in addition to the evidence of the evenness index values, NMDS indicates a higher similarity among picoplankton samples, relative to nano- and microplankton, but no clear separation of the regions. This conservative picoplankton distributional pattern is in spite of the fact the environmental conditions are differentiated among the regions, especially for Vaigat Strait. We studied diversity in samples collected in close spatial and temporal proximity and have demonstrated clear differences in distribution of micro- and nanoplankton. These findings are supported by other metabarcoding studies (De Vargas et al., 2015; Kilias et al., 2014b; Massana et al., 2015); intraspecific investigations have also demonstrated structured phytoplankton populations (Alpermann et al., 2010; Kremp et al., 2014; Masseret et al., 2009; Tahvanainen et al., 2012). However, the view is not so clear for the picoplankton community. Obviously, regional environmental constraints play a role in community structuring, with a stronger structuring evident for larger organismal size- fractions and increasing dispersal limitation ranging from small cells to larger cells (De Vargas et al., 2015).

\subsection{Group diversity of the eukaryotic plankton community}

The alveolates and stramenopiles were commonly detected in high relative abundance within west Greenland coastal waters. The placement of OTUs on the two concatenated phylogenetic trees not only addresses the issue of over- or underrepresentation of diversity, but also permitted assignment of $78.8 \%$ and $84.9 \%$ of the OTUs to generic category for alveolates and stramenopiles, respectively (Table 1).

\subsubsection{Stramenopiles, especially diatoms}

For west Greenland, chain-forming diatom species, such as those of Chaetoceros (Mediophyceae), Fragilariopsis (Bacillariophyceae) and Thalassiosira (Mediophyceae) and at lower densities of Navicula (Bacillariophyceae), Pseudo-nitzschia (Bacillariophyceae) and Skeletonema (Mediophyceae), have been previously reported (Krawczyk et al., 2014; Zamora-Terol et al., 2013). The genus Chaetoceros is the most abundant, as inferred from molecular sequence data $(\sim 100,000$ OTUs), especially within Vaigat Strait, supporting previous reports of this genus as one of the most abundant in Arctic-subarctic waters (Berard-Therriault and Poulin, 1999; Østrup, 1895; Throndsen et al., 2007; von Quillfeldt, 2000). However, the Chaetoceros lineage is very diverse and includes many species that are difficult to identify. Chaetoceros species have been found in more saline open marine waters in the Davis Strait south of $70^{\circ} \mathrm{N}$ (Krawczyk et al., 2014). Chaetoceros neogracile accounts for more than the half of all OTUs associated with Chaetoceros, whereas three other species, 
namely $C$. debilis, $C$. lorenzianus, and $C$. radicans, were also found in our study. In other studies in central northern Baffin Bay, Chaetoceros species have been previously observed to be a prominent part of the micro-phytoplankton community in July to September (Booth et al., 2002; Lovejoy et al., 2002).

Thalassiosira species are abundant in the Vaigat region, but only $T$. nodulolineata, an uncommonly recorded taxon, was identified to species level. Off the west coast of Greenland, Thalassiosira species, such as $T$. nordenskioldii and $T$. poroseriata, have been reported among the dominant taxa, especially in summer (von Quillfeldt, 2000). Krawczyk et al. (2014) described the diatom distribution from southwest to west Greenland and found that other Thalassiosira species were common in coastal waters (mainly Godthabsfjord/Nuuk) and linked to increased surface temperature, typical for summer water stratification in this area. Moreover, there is a clear spring bloom scenario for West Greenland with a relatively high biomass of Thalassiosira species based on samples collected during different years and seasons (Zamora-Terol et al., 2013). However, the overall occurrence of Thalassiosira species may vary widely due to the annual succession processes.

In our study, we did not detect any OTU related to Fragilariopsis, although such species are associated with and often dominant at high latitudes in the entire circumpolar area, particularly during the spring bloom, and are often associated with ice (Lundholm and Hasle, 2010). Krawczyk et al. (2014) observed a small number of cells of Fragilariopsis in west Greenland. We may have missed Fragilariopsis because of the seasonal mismatch because their study was conducted during June-July 2007, whereas we sampled during July-August 2012.

The genus Skeletonema represents a large and diverse lineage of globally distributed diatoms and has been often referred to the $S$. costatum species complex (Kooistra et al., 2008; McDonald et al., 2007; Sarno et al., 2005). In our study, we did not identify to species level, but we observed Skeletonema in higher OTU abundance especially in stratified waters at the head of Uummannaq Fjord and at Stations 512-514 from Vaigat Strait to Disko Bay passage influenced by glacial melt water. This result agrees with Ilyash et al. (2014), who also observed Skeletonema within Dvina Bay (White Sea) characterized by pronounced freshwater-driven stratification.

\subsubsection{Alveolates, especially dinophytes}

The contribution of alveolate OTUs to the community diversity was particularly high among the nanoplankton. Dominant dinophyte OTUs identified in our study have been previously reported from cold waters. Protoperidinium (Peridiniales) is diverse in North Atlantic waters and abundant in biomass particularly during summer (Bachy et al., 2012; Lovejoy et al., 2002; Mertens et al., 2013; Okolodkov, 1998; Okolodkov and Dodge, 1997; Y.B., 1998; Yamaguchi et al., 2006, 2005). Another taxon of uncertain phylogenetic position in the dinophyte tree, but determined as Gyrodinium nom. cons. (Christensen, 1987; Silva, 1980), has been collected before in northern Denmark (Hansen and Daudbjerg, 2004) and northern Japan (Takano and Horiguchi, 2004).

All observed OTUs assigned to Biecheleria (Suessiales) are associated with $B$. baltica (="Woloszynskia" halophila), which is a rather well known cold-water species optimally growing at $0-6{ }^{\circ} \mathrm{C}$ (Kremp et al., 2005; Moestrup et al., 2009; Warns et al., 2013). However, it has been considered to be restricted to brackish water with salinities of 6 30. Although there are freshwater influences at Baffin Bay (Tang et al., 2004), salinity and temperature differ from the reported tolerance spectra for this species (Kremp et al., 2005; Moestrup et al., 2009; Warns et al., 2013). Biecheleria species have been recently reported from Hudson Bay (Heikkilä et al., 2014), and also in Arctic sea-ice samples (Bachy et al., 2012), both geographically and ecologically relatively close to our study regime.

\subsubsection{Other phylogenetic lineages}

The high relative abundance of Viridiplantae within the picoplankton comprises Chlorophyta (e.g., Prasinophyceae) and Streptophyta but most OTUs were only assignable to the lineage Viridiplantae. Little is known about these small-sized phytoplankton; nevertheless, within the small nano- and picoplankton, Chlorophyta are especially important in marine waters (Not et al., 2012). Most SSU rRNA sequences recovered from the oceanic environment correspond to the polyphyletic group of Prasinophyceae (Guillou et al., 2004).

Metazoans were especially abundant in microplankton samples of Stations 509 and 505 and the nanoplankton sample at Station 504. This group includes, for example, Arthropoda, Cnidaria or Porifera, and is usually not considered as part of the micro- or nanoplankton, as their organismal size is typically larger. Nevertheless, organismal fragments or gametes of this group may be collected during sampling and subsequently detected by NGS.

\subsection{Potential $H A B$ taxa within the transect}

High temporal and spatial sample throughput offered by NGS provides reliable comparison and confirmation of potentially false classification based only on morphological analysis. For example, if the conventional taxonomy of potentially toxic species is well known, even in cases for which the nomenclature remains controversial, e.g., for genus Alexandrium (John et al., 2015), unequivocal identification of the taxon can be confirmed. Among the potentially toxigenic plankton that may cause harmful algal blooms (HABs) when present in high cell numbers, we detected OTUs corresponding to members of the genera Alexandrium, Dinophysis, Gonyaulax, Gymnodinium, Prorocentrum and Pseudo-nitzschia (Table S9). To date OTU sequences can only support interpretations with great uncertainties and quantitative techniques, such as qPCR, must be applied for species verification. Nevertheless, as evidence of how toxins and species presence may be related, at three stations we were able to confirm OTUs corresponding to the non-toxic A. tamutum, the toxic $A$. fundyense (Group I) and typically toxigenic A. ostenfeldii, with a qPCR assay to reliably differentiate and discriminate between toxic and non-toxic Alexandrium species. At Station 516, OTUs assigned to Alexandrium species peaked (at 373 of 60,038 total reads per station), which matches with the presence of paralytic shellfish poisoning (PSP) and spirolide (SPX) toxins at this station. However, given the high detection limit of PSP toxins, we might have missed detection of low levels of these toxins at other stations. The A. tamutum isolates from Greenland have been confirmed as non-toxigenic, but $A$. fundyense (Group I) isolates were all PSP toxin-producers (Tillmann et al., 2016). The spirolides (SPXs) have a lower detection limit by LC-MS/MS than PSP toxins and hence were detected at all stations. Highest SPX concentrations were detected at Station 516, where A. ostenfeldii was also identified from OTU sequences, by subsequent qPCR and from other Greenland and Arctic stations (Tillmann et al., 2014).

For Vaigat Strait, we have shown that higher chl $a$ concentrations, and depleted silicate and phosphate concentrations, correspond to a higher relative abundance of diatoms. Nevertheless, OTUs assigned to Pseudo-nitzschia (Bacillariophyceae), the potential producer of the neurotoxin domoic acid (DA), were only detected in low read numbers (8-40 of $\sim 28,000-50,000$ total reads per station, Table S9). This matches with the lower DA concentrations in plankton from Vaigat Strait compared to Uummannaq Fjord and at Stations 516 and 517. In contrast, no DA was measured at the head of the Uummannaq Fjord (Station 506 and 507) and Station 514, although here we detected higher numbers of OTU reads assigned to Pseudo-nitzschia, as well as higher silicate and phosphate concentrations that would support diatom growth. The DA production within Pseudo-nitzschia cells is influenced by growth conditions and induced nutrient limitation (of phosphate or silicate), therefore cell concentration does not necessary correlate with toxin concentration (Lelong et al., 2012). 
Dinophysis (Dinophyceae) is known producer of dinophysistoxins (DTX) and okadaic acid (OA), as well as of pectenotoxins (PTX). The OTUs assigned to Dinophysis were detected in low numbers in Uummannaq Fjord and at Disko Bay stations (1-11 of 15,00060,000 total reads per station, Table S9). Both DTX and OA have a relatively high detection limit by LC-MS/MS analysis, which might be the reason why we did not detect these toxins at some stations where corresponding OTUs were found (Table S8), but pectenotoxins (PTXs) have a lower detection limit and were detected at all stations. Diatoms were dominant within the Vaigat Strait, and the overall relative low abundances of Dinophyceae within this area may explain the lack of Dinophysis signatures.

Although we did not find blooms of any potentially harmful algae, as defined by high cell concentrations, we were able to associate the presence of OTUs identified by molecular diversity probes with toxin signals in the plankton. In this fashion, NGS may be used to detect potentially toxigenic species even in general monitoring or research surveys. In any case, environmental shifts may increase risks for HABs in areas where toxigenic taxa have already been detected. Increasing surface water temperature may have a positive effect on dinoflagellate species and cell abundance and thus increase the potential for HAB events in the Arctic.

\section{Conclusion}

We conclude that the diversity of the small phytoplankton is differently affected by abiotic factors compared to larger cells. The higher diversity of the small cells may compensate for their lower phenotypic plasticity. We suggest the possibility of an advantage of the small cell-size community in response to changing environmental conditions. To address further questions about the ecological function of size-class differentiation, functional analysis (e.g., based on mRNA) must be considered and included in future studies and rRNA-based diversity surveys. In the Arctic, if species composition of plankton communities changes, particularly with respect to an increase of potentially toxic and/or otherwise harmful algae, the livelihood and well-being of coastal communities in Greenland may be profoundly and negatively affected.

\section{Acknowledgements}

We thank the captain and crew of $R V$ Maria $S$. Merian for assistance with the collection of samples. We are grateful to Daniela Meier and Rohan Henkel (ICBM, Oldenburg University) for their operation of the CTD-water sampler, to Nancy Kühne and Annegret Müller (AWI) for their technical support in the laboratory and to Claudia Burau and Kai-Uwe Ludwichowski (AWI) for the nutrient analysis. We acknowledge the work of the Max Planck Genome Center (Cologne, Germany) for their sequencing effort (454 GS FLX sequencer). The expedition was conducted within the framework of the SCOR/ IOC GEOHAB Core Research Project on HABs in Fjords and Coastal Embayments and was financially and logistically supported under the PACES II Programme of the Alfred Wegener Institute, Helmholtz Centre for Polar and Marine Research, Germany.

\section{Appendix A. Supporting information}

Supplementary data associated with this article can be found in the online version at doi:10.1016/j.dsr.2016.11.002.

\section{References}

Adl, S.M., 2013. Algal taxonomy: ready to play. J. Phycol. 49, (226-226).

Alpermann, T.J., Tillmann, U., Beszteri, B., Cembella, A.D., John, U., 2010. Phenotypic variation and genotypic diversity in a planktonic population of the toxigenic marine dinoflagellate Alexandrium tamarense (Dinophyceae). J. Phycol. 46, 18-32.
Armstrong, F.A.J., Stearns, C.R., Strickland, J.D.H., 1967. The measurement of upwelling and subsequent biological process by means of the Technicon Autoanalyzer and associated equipment. Deep Sea Res. Oceanogr. Abstr. 14, 381-389.

Bachy, C., Dolan, J.R., López-García, P., Deschamps, P., Moreira, D., 2012. Accuracy of protist diversity assessments: morphology compared with cloning and direct pyrosequencing of $18 \mathrm{~S}$ rRNA genes and ITS regions using the conspicuous tintinnid ciliates as a case study. ISME J. 7, 244-255.

Berard-Therriault, L., Poulin, M., 1999. Guide d'identification du phytoplancton marin de l'estuaire et du golfe du Saint-Laurent incluant également certains protozoaires. Can. Spec. Publ. Fish. Aquat. Sci. 128, 387.

Bik, H.M., Porazinska, D.L., Creer, S., Caporaso, J.G., Knight, R., Thomas, W.K., 2012. Sequencing our way towards understanding global eukaryotic biodiversity. Trends Ecol. Evol. 27, 233-243.

Bittner, L., Gobet, A., Audic, S., Romac, S., Egge, E.S., Santini, S., Ogata, H., Probert, I., Edvardsen, B., De Vargas, C., 2013. Diversity patterns of uncultured Haptophytes unravelled by pyrosequencing in Naples Bay. Mol. Ecol. 22, 87-101.

Booth, B.C., Larouche, P., Bélanger, S., Klein, B., Amiel, D., Mei, Z.P., 2002. Dynamics of Chaetoceros socialis blooms in the North. Water Deep. Res. Part II Top. Stud. Oceanogr. 49, 5003-5025.

Caporaso, J.G., Kuczynski, J., Stombaugh, J., Bittinger, K., Bushman, F.D., Costello, E.K., Fierer, N., Peña, A.G., Goodrich, J.K., Gordon, J.I., Huttley, G.A., Kelley, S.T., Knights, D., Koenig, J.E., Ley, R.E., Lozupone, C.A., McDonald, D., Muegge, B.D., Pirrung, M., Reeder, J., Sevinsky, J.R., Turnbaugh, P.J., Walters, W.A., Widmann, J., Yatsunenko, T., Zaneveld, J., Knight, R., 2010. QIIME allows analysis of highthroughput community sequencing data. Nat. Methods.

Christensen, T., 1987. Report of the committee for algae. Taxon 36, 66-69.

Countway, P.D., Vigil, P.D., Schnetzer, A., Moorthi, S.D., Caron, D. a., 2010. Seasonal analysis of protistan community structure and diversity at the USC Microbial Observatory (San Pedro Channel, North Pacific Ocean). Limnol. Oceanogr. 55, 2381-2396.

De Vargas, C., Audic, S., Henry, N., Decelle, J., Mahé, F., Logares, R., Lara, E., Berney, C., Bescot, N., Le, Probert, I., Carmichael, M., Poulain, J., Romac, S., 2015. Eukaryotic plankton diversity in the sunlit ocean. Science 348, 12616051.

Dünweber, M., Swalethorp, R., Kjellerup, S., Nielsen, T.G., Arendt, K.E., Hjorth, M., Tönnesson, K., Møller, E.F., 2010. Succession and fate of the spring diatom bloom in Disko Bay, western Greenland. Mar. Ecol. Prog. Ser. 419, 11-29.

Eberlein, K., Kattner, G., 2000. Automatic method for the determination of orthophosphate and total dissolved phosphorus in the marine environment turns, 354-357.

Egge, E., Bittner, L., Andersen, T., Audic, S., de Vargas, C., Edvardsen, B., 2013. 454 pyrosequencing to describe microbial eukaryotic community composition, diversity and relative abundance: a test for marine Haptophytes. PLoS One, 8.

Egge, E.S., Eikrem, W., Edvardsen, B., 2014. Deep-branching novel lineages and high diversity of haptophytes in the Skagerrak (Norway) uncovered by 454 pyrosequencing. J. Eukaryot. Microbiol., 121-140.

Falkowski, P.G., Barber, R.T., Smetacek, V., 1998. Biogeochem. Controls Feedbacks Ocean Prim. Prod. 281, 200-206.

Fenchel, T., Finlay, B.J., 2004. The ubiquity of small species: patterns of local and global diversity. Bioscience 54, 777.

Field, C.B., 1998. Primary production of the biosphere: integrating terrestrial and oceanic components. Science 281, 237-240.

Gottschling, M., Söhner, S., Zinßmeister, C., John, U., Plötner, J., Schweikert, M. Aligizaki, K., Elbrächter, M., 2012. Delimitation of the Thoracosphaeraceae (Dinophyceae), including the calcareous dinoflagellates, based on large amounts of ribosomal RNA sequence data. Protist 163, 15-24.

Grasshoff, K., Ehrhardt, M., Kremling, K., 1983. Methods of Seawaters Analysis. Verlag Chemie.

Guillou, L., Eikrem, W., Chrétiennot-Dinet, M.-J., Le Gall, F., Massana, R., Romari, K., Pedrós-Alió, C., Vaulot, D., 2004. Diversity of picoplanktonic prasinophytes assessed by direct nuclear SSU rDNA sequencing of environmental samples and novel isolates retrieved from oceanic and coastal marine ecosystems. Protist 155, 193-214.

Hanna, E., Huybrechts, P., Steffen, K., Cappelen, J., Huff, R., Shuman, C., Irvine-Fynn, T., Wise, S., Griffiths, M., 2008. Increased runoff from melt from the greenland ice sheet: a response to global warming. J. Clim. 21, 331-341.

Hansen, A.S., Nielsen, T.G., Levinsen, H., Madsen, S.D., Thingstad, T.F., Hansen, B.W., 2003. Impact of changing ice cover on pelagic productivity and food web structure in Disko Bay, West Greenland: a dynamic model approach. Deep. Res. Part I Oceanogr. Res. Pap. 50, 171-187.

Hansen, G., Daudbjerg, N., 2004. Ultrastructure of Gyrodinium spirale, the type species of Gyrodinium (Dinophyceae), including a phylogeneny of G. dominans, G. rubrum and G. spirale deduced from partial LSU rDNA sequences. Protist 155, 271-294.

Hansen, M.O., Gissel Nielsen, T., Stedmon, C. a., Munk, P., 2012. Oceanographic regime shift during 1997 in Disko Bay, Western Greenland. Limnol. Oceanogr. 57, 634-644.

Hasle, G.R., Lange, C.B., Syvertsen, E.E., 1996. A review of Pseudo-nitzschia, with special reference to the Skagerrak, North Atlantic, and adjacent waters. Helgoländer Meeresunters. 50, 131-175.

Heikkilä, M., Pospelova, V., Hochheim, K.P., Kuzyk, Z.Z.A., Stern, G.A., Barber, D.G., Macdonald, R.W., 2014. Surface sediment dinoflagellate cysts from the Hudson Bay system and their relation to freshwater and nutrient cycling. Mar. Micropaleontol. 106, 79-109.

Holinde, L., Zielinski, O., 2015. Bio-optical characterization and light availability parametrization in two glacial melt water influenced estuary systems (WestGreenland). Ocean Sci. Discuss. 12, 1537-1566.

Huber, J. a., Morrison, H.G., Huse, S.M., Neal, P.R., Sogin, M.L., Mark Welch, D.B., 2009. Effect of PCR amplicon size on assessments of clone library microbial diversity 
and community structure. Environ. Microbiol. 11, 1292-1302.

Ilyash, L.V., Radchenko, I.G., Shevchenko, V.P., Zdorovennov, R.E., Pantyulin, a.N., 2014. Contrasting summer phytoplankton communities in stratified and mixed waters of the white sea. Oceanology 54, 730-738.

Isbell, F., Calcagno, V., Hector, A., Connolly, J., Harpole, W.S., Reich, P.B., SchererLorenzen, M., Schmid, B., Tilman, D., van Ruijven, J., Weigelt, A., Wilsey, B.J., Zavaleta, E.S., Loreau, M., 2011. High plant diversity is needed to maintain ecosystem services. Nature 477, 199-202.

John, U., Fensome, R.A., Medlin, L.K., 2003. The application of a molecular clock based on molecular sequences and the fossil record to explain biogeographic distributions within the Alexandrium tamarense "species complex" (Dinophyceae). Mol. Biol. Evol. 20, 1015-1027.

John, U., Medlin, L.K., Groben, R., 2005. Development of specific rRNA probes to distinguish between geographic clades of the Alexandrium tamarense species complex. J. Plankton Res. 27, 199-204.

John, U., Tillmann, U., Hulskotter, J., Alpermann, T.J., Wohlrab, S., Van de Waal, D.B., 2015. Intraspecific facilitation by allelochemical mediated grazing protection within a toxigenic dinoflagellate population. Proc. R. Soc. B Biol. Sci. 282, (2014126820141268).

Juul-Pedersen, T., Nielsen, T.G., Michel, C., Møller, E.F., Tiselius, P., Thor, P., Olesen, M., Selander, E., Gooding, S., 2006. Sedimentation following the spring bloom in Disko Bay, West Greenland, with special emphasis on the role of copepods. Mar. Ecol. Prog. Ser. 314, 239-255.

Kerimoglu, O., Straile, D., Peeters, F., 2012. Incompletely Mixed Systems 300, 330-343.

Kilias, E.S., Kattner, G., Wolf, C., Frickenhaus, S., Metfies, K., 2014a. A molecular survey of protist diversity through the central Arctic Ocean. Polar Biol. 37, 1271-1287.

Kilias, E.S., Nöthig, E.M., Wolf, C., Metfies, K., 2014b. Picoeukaryote plankton composition off West Spitsbergen at the entrance to the Arctic Ocean. J. Eukaryot. Microbiol. 0, 1-11.

Kooistra, W.H.C.F., Sarno, D., Balzano, S., Gu, H., Andersen, R. a., Zingone, A., 2008. Global diversity and biogeography of Skeletonema species (Bacillariophyta). Protist 159, 177-193.

Koroleff, F., 1969. Direct determination of ammonia in natural waters as indophenol blue. Int. Con. Explor. Sea, C. C.

Krauss, W., 1995. Currents and mixing in the Irminger Sea and in the Iceland Basin. J. Geophys. Res. 100, 10851.

Krawczyk, D.W., Witkowski, A., Waniek, J.J., Wroniecki, M., Harff, J., 2014. Description of diatoms from the Southwest to West Greenland coastal and open marine waters. Polar Biol. 37, 1589-1606.

Kremp, A., Elbrächter, M., Schweikert, M., Wolny, J.L., Gottschling, M., 2005. Woloszynskia halophila (Biecheler) comb. nov.: a bloom-forming cold-water dinoflagellate co-occurring with Scrippsiella hangoei (Dinophyceae) in the Baltic Sea. J. Phycol. 41, 629-642.

Kretschmann, J., Filipowicz, N.H., Owsianny, P.M., Zinssmeister, C., Gottschling, M., 2015. Taxonomic clarification of the unusual dinophyte Gymnodinium limneticum Wołosz. (Gymnodiniaceae) from the Tatra Mountains. Protist 166, 621-637.

Krock, B., Tillmann, U., John, U., Cembella, A., 2008. LC-MS-MS aboard ship: tandem mass spectrometry in the search for phycotoxins and novel toxigenic plankton from the North Sea. Anal. Bioanal. Chem. 392, 797-803.

Kunin, V., Engelbrektson, A., Ochman, H., Hugenholtz, P., 2010. Wrinkles in the rare biosphere: pyrosequencing errors can lead to artificial inflation of diversity estimates. Environ. Microbiol. 12, 118-123.

Legendre, P., Gallagher, E.D., 2001. Ecologically meaningful transformations for ordination of species data. Oecologia 129, 271-280.

Lelong, A., Hégaret, H., Soudant, P., Bates, S.S., 2012. Pseudo-nitzschia (Bacillariophyceae) species, domoic acid and amnesic shellfish poisoning: revisiting previous paradigms. Phycologia 51, 168-216.

Levinsen, H., Turner, J.T., Nielsen, T.G., Hansen, B.W., 2000. On the trophic coupling between protists and copepods in arctic marine ecosystems. Mar. Ecol. Prog. Ser. 204, 65-77.

Litchman, E., Klausmeier, C.A., 2008. Trait-based community ecology of phytoplankton. Annu. Rev. Ecol. Evol. Syst. 39, 615-639.

Litchman, E., Klausmeier, C.A., Yoshiyama, K., 2009. Contrasting size evolution in marine and freshwater diatoms 106, 2665-2670.

Litchman, E., Klausmeier, C. a., Schofield, O.M., Falkowski, P.G., 2007. The role of functional traits and trade-offs in structuring phytoplankton communities: scaling from cellular to ecosystem level. Ecol. Lett. 10, 1170-1181.

López-García, P., Rodríguez-Valera, F., Pedrós-Alió, C., Moreira, D., 2001. Unexpected diversity of small eukaryotes in deep-sea Antarctic plankton. Nature 409, 603-607.

Loreau, M., Naeem, S., Inchausti, P., Bengtsson, J., Grime, J.P., Hector, A., Hooper, D.U., Huston, M.A., Raffaelli, D., Schmid, B., Tilman, D., Wardle, D.A., 2001. Biodiversity and ecosystem functioning: current knowledge and future challenges. Science 294, 804-808.

Lovejoy, C., Legendre, L., Martineau, M.J., Bâcle, J., Von Quillfeldt, C.H., 2002. Distribution of phytoplankton and other protists in the North. Water Deep. Res. Part II Top. Stud. Oceanogr. 49, 5027-5047.

Lundholm, N., Hasle, G.R., 2010. Fragilariopsis (Bacillariophyceae) of the Northern Hemisphere - morphology, taxonomy, phylogeny and distribution, with a description of $F$. pacifica sp. nov. Phycologia 49, 438-460.

Madsen, S.D., Nielsen, T.G., Hansen, B.W., 2001. Annual population development and production by Calanus finmarchicus, C. glacialis and C. hyperboreus in Disko Bay, western Greenland. Mar. Biol. 139, 75-93.

Magurran, A., 2004. Measuring biological diversity. Afr. J. Aquat. Sci. 29, 285-286.

Massana, R., Gobet, A., Audic, S., Bass, D., Bittner, L., Boutte, C., Chambouvet, A., Christen, R., Claverie, J., Decelle, J., Dolan, J.R., Dunthorn, M., Edvardsen, B., Forn, I., Forster, D., Guillou, L., Jaillon, O., Kooistra, W.H.C.F., Logares, R., Mahé, F., Not,
F., Ogata, H., Pawlowski, J., Pernice, M.C., Probert, I., Romac, S., Richards, T., Santini, S., Shalchian-Tabrizi, K., Siano, R., Simon, N., Stoeck, T., Vaulot, D., Zingone, A., de Vargas, C., 2015. Marine protist diversity in European coastal waters and sediments as revealed by high-throughput sequencing. Environ. Microbiol. 17, 4035-4049.

Masseret, E., Grzebyk, D., Nagai, S., Genovesi, B., Lasserre, B., Laabir, M., Collos, Y., Vaquer, A., Berrebi, P., 2009. Unexpected genetic diversity among and within populations of the toxic dinoflagellate Alexandrium catenella as revealed by nuclear microsatellite markers. Appl. Environ. Microbiol. 75, 2037-2045.

McDonald, S.M., Sarno, D., Scanlan, D.J., Zingone, A., 2007. Genetic diversity of eukaryotic ultraphytoplankton in the Gulf of Naples during an annual cycle. Aquat. Microb. Ecol. 50, 75-89.

McMurdie, P.J., Holmes, S., 2014. Waste not, want not: why rarefying microbiome data is inadmissible. PLoS Comput. Biol., 10.

Medlin, L.K., 2007. If everything is everywhere, do they share a common gene pool? Gene 406, 180-183.

Medlin, L.K., Kooistra, W.H.C.F., 2010. Methods to estimate the diversity in the marine photosynthetic protist community with illustrations from case studies: a review, Diversity.

Medlin, L.K., Lange, M., Wellbrock, U., Donner, G., Elbrächter, M., Hummert, C., Luckas, B., 1998. Sequence comparisons link toxic European isolates of Alexandrium tamarense from the Orkney Islands to toxic North American stocks. Eur. J. Protistol. 34, 329-335.

Mertens, K.N., Yamaguchi, A., Takano, Y., Pospelova, V., Head, M.J., Radi, T., Pieńkowski, A.J., de Vernal, A., Kawami, H., Matsuoka, K., 2013. A new heterotrophic dinoflagellate from the North-eastern Pacific, Protoperidinium fukuyoi: cyst-theca relationship, phylogeny, distribution and ecology. J. Eukaryot. Microbiol. 60, 545-563.

Meyer, M., Stenzel, U., Myles, S., Prüfer, K., Hofreiter, M., 2007. Targeted highthroughput sequencing of tagged nucleic acid samples. Nucleic Acids Res 35, e97.

Moestrup, Ø., Lindberg, K., Daugbjerg, N., 2009. Studies on woloszynskioid dinoflagellates IV: the genus Biecheleria gen. nov. Phycol. Res 57, 203-220.

Moniz, M.B.J., Kaczmarska, I., 2009. Barcoding diatoms: is there a good marker? Mol. Ecol. Resour. 9, 65-74.

Moon-van der Staay, S.Y., De Wachter, R., Vaulot, D., 2001. Oceanic 18S rDNA sequences from picoplankton reveal unsuspected eukaryotic diversity. Nature 409, 607-610.

Nielsen, G.T., 2005. Struktur og funktion af fødenettet i havets frie vandmasser. Miljøundersøgelser. Miljøministeriet, 71.

Not, F., Siano, R., Kooistra, W.H.C.F., Simon, N., Vaulot, D., Probert, I., 2012. Diversity and ecology of eukaryotic marine phytoplankton. Adv. Botanical Res.

Okolodkov, Y.B., 1998. A checklist of dinoflagellates recorded from the Russian Arctic seas. Sarsia 83, 267-292.

Okolodkov, Y.B., Dodge, J.D., 1997. Morphology of some rare unusual dinoflagellates from the north-eastern Atlantic. Nov. Hedwigia 64, 353-365.

Oksanen, J., Blanchet, F.G., Kindt, R., Legendre, P., Minchin, P.R., O’Hara, R.B., Simpson, G.L., Solymos, P., Stevens, M.H.H., Wagner, H., 2013. Package "vegan.” R Packag. ver. 2.0-8.

Østrup, E., 1895. Marine diatomeer fra Østgrønland XVIII, 397-476.

Pachauri, R.K., Allen, M.R., Barros, V.R., Broome, J., Cramer, W., Christ, R., Church, J. A., Clarke, L., Dahe, Q., Dasgupta, P., Dubash, N.K., Edenhofer, O., Elgizouli, I., Field, C.B., Forster, P., Friedlingstein, P., Fuglestvedt, J., Gomez-Echeverri, L., Hallegatte, S., Hegerl, G., Howden, M., Jiang, K., Jimenez Cisneroz, B., Kattsov, V., Lee, H., Mach, K.J., Marotzke, J., Mastrandrea, M.D., Meyer, L., Minx, J., Mulugetta, Y., O’Brien, K., Oppenheimer, M., Pereira, J.J., Pichs-Madruga, R., Plattner, G.-K., Pörtner, H.-O., Power, S.B., Preston, B., Ravindranath, N.H., Reisinger, A., Riahi, K., Rusticucci, M., Scholes, R., Seyboth, K., Sokona, Y., Stavins, R., Stocker, T.F., Tschakert, P., van Vuuren, D., van Ypserle, J.-P., 2014. Climate Change 2014: Synthesis Report. Contribution of Working Groups I, II and III to the Fifth Assessment Report of the Intergovernmental Panel on Climate Change.

Pančić, M., Hansen, P.J., Tammilehto, A., Lundholm, N., 2015. Resilience to temperature and $\mathrm{pH}$ changes in a future climate change scenario in six strains of the polar diatom Fragilariopsis cylindrus. Biogeosciences 12, 4235-4244.

Poulin, M., Daugbjerg, N., Gradinger, R., Ilyash, L., Ratkova, T., von Quillfeldt, C., 2011. The pan-Arctic biodiversity of marine pelagic and sea-ice unicellular eukaryotes: a first-attempt assessment. Mar. Biodivers. 41, 13-28.

Ptacnik, R., Solimini, A.G., Andersen, T., Tamminen, T., Brettum, P., Lepist, L., Willén, E., Rekolainen, S., 2008. Diversity predicts stability and resource use efficiency in natural phytoplankton communities. PNAS 105, 5134-5138.

R Development Core Team, R., 2011. R: A language and environment for statistical computing. R Foundation for Statistical Computing.

Rao, C.R., 1995. A review of canonical coordinates and an alternative to correspondence analysis using hellinger distance. Questiió Quad. d’Estadística, Sist. Inform. Investig. Oper. 19, 23-63.

Reeder, J., Knight, R., 2009. The "rare biosphere": a reality check. Nat. Methods 6, 636-637.

Rengefors, K., Logares, R., Laybourn-parry, J., Gast, R.J., 2015. Evidence of concurrent local adaptation and high phenotypic plasticity in a polar microeukaryote 17, 1510-1519.

Sarno, D., Kooistra, W.H.C.F., Medlin, L.K., Percopo, I., Zingone, A., 2005. Diversity in the genus Skeletonema (Bacillariophyceae). II. An assessment of the taxonomy of $S$. costatum-like species with the description of four new species. J. Phycol. 41, 151-176.

Schloss, P.D., Handelsman, J., 2005. Introducing DOTUR, a computer program for defining operational taxonomic units and estimating species richness. Appl. Environ. Microbiol. 71, 1501-1506. 
Scholin, C.A., Herzog, M., Sogn, M., Anderson, M., 1994. Identification of group- and strain-specific genetic markers for globally distributed Alexandrium (Dinophyceae). II. Sequence analysis of a fragment of the LSU rRNA gene. J. Phycol. 30. 6, 999-1011.

Sha, L., Jiang, H., Seidenkrantz, M.-S., Knudsen, K.L., Olsen, J., Kuijpers, A., Liu, Y., 2014. A diatom-based sea-ice reconstruction for the Vaigat Strait (Disko Bugt, West Greenland) over the last 5000 yr. Palaeogeogr. Palaeoclimatol. Palaeoecol. 403, 66-79.

Silva, P.C., 1980. Remarks on algal nomenclature VI. Taxon, 121-145.

Smith, S.L., Merico, A., Wirtz, K.W., Pahlow, M., 2014. Leaving misleading legacies behind in plankton ecosystem modelling. J. Plankton Res. 36, 613-620.

Sogin, M.L., Morrison, H.G., Huber, J.A., Welch, D.M., Huse, S.M., Neal, P.R., Arrieta, J.M., Herndl, G.J., 2006. Microbial diversity in the deep sea and the underexplored "rare biosphere". PNAS 10, 12115-12120.

Sonnenberg, R., Nolte, A.W., Tautz, D., 2007. An evaluation of LSU rDNA D1-D2 sequences for their use in species identification. Front. Zool. 4, 6.

Stecher, A., Neuhaus, S., Lange, B., Frickenhaus, S., Beszteri, B., Kroth, P.G., Valentin, K., 2015. rRNA and rDNA based assessment of sea ice protist biodiversity from the central Arctic Ocean. Eur. J. Phycol. 262, 1-16.

Stocker, T.F., 2014. Climate change 2013: the physical science basis: working group I contribution to the fifth assessment report of the intergovernmental panel on climate change. Cambridge University Press.

Stoeck, T., Bass, D., Nebel, M., Christen, R., Jones, M.D.M., Breiner, H.W., Richards, T. a., 2010. Multiple marker parallel tag environmental DNA sequencing reveals a highly complex eukaryotic community in marine anoxic water. Mol. Ecol. 19, 21-31.

Straneo, F., Cenedese, C., 2015. The dynamics of Greenland's glacial fjords and their role in climate. Ann. Rev. Mar. Sci. 7, 89-112.

Striebel, M., Behl, S., Diehl, S., Stibor, H., 2009. Spectral niche complementarity and carbon dynamics in pelagic ecosystems. Am. Nat. 174, 141-147.

Suikkanen, S., Kremp, A., Hautala, H., Krock, B., 2013. Paralytic shellfish toxins or spirolides? The role of environmental and genetic factors in toxin production of the Alexandrium ostenfeldii complex. Harmful Algae 26, 52-59.

Swift, J.H., Aagaard, K., 1981. Seasonal transitions and water mass formation in the Iceland and Greenland seas. Deep Sea Res. Part A. Oceanogr. Res. Pap., 28.

Taberlet, P., Coissac, E., Pompanon, F., Brochmann, C., Willerslev, E., 2012. Towards next-generation biodiversity assessment using DNA metabarcoding. Mol. Ecol. 21, 2045-2050.

Tahvanainen, P., Alpermann, T.J., Figueroa, R.I., John, U., Hakanen, P., Nagai, S., Blomster, J., Kremp, A., 2012. Patterns of post-glacial genetic differentiation in marginal populations of a marine microalga. PLoS One 7, e53602.

Takano, Y., Horiguchi, T., 2004. Surface ultrastructure and molecular phylogenetics of four unarmored heterotrophic dinoflagellates, including the type species of the genus Gyrodinium (Dinophyceae). Phycol. Res., 107-116.

Tang, C.C.L., Ross, C.K., Yao, T., Petrie, B., DeTracey, B.M., Dunlap, E., 2004. The circulation, water masses and sea-ice of Baffin Bay. Prog. Oceanogr. 63, 183-228.

Terlizzi, A., Anderson, M.J., Bevilacqua, S., Fraschetti, S., Włodarska-Kowalczuk, M., Ellingsen, K.E., 2009. Beta diversity and taxonomic sufficiency: do higher-level taxa reflect heterogeneity in species composition? Divers. Distrib. 15, 450-458.

Thoisen, C., Riisgaard, K., Lundholm, N., Nielsen, T., Hansen, P., 2015. Effect of acidification on an Arctic phytoplankton community from Disko Bay, West Greenland. Mar. Ecol. Prog. Ser. 520, 21-34.

Thomas, M.K., Kremer, C.T., Klausmeier, C. a., Litchman, E., 2012. A global pattern of thermal adaptation in marine phytoplankton. Science 338, 1085-1089.
Throndsen, J., Hasle, G., Tangen, K., 2007. Phytoplankton of Norwegian coastal waters. Almater Forl., 341.

Tillmann, U., Kremp, A., Tahvanainen, P., Krock, B., 2014. Characterization of spirolide producing Alexandrium ostenfeldii (Dinophyceae) from the western Arctic. Harmful Algae 39, 259-270.

Tillmann, U., Krock, B., Alpermann, T.J., Cembella, A., 2016. Bioactive compounds of marine dinoflagellate isolates from western Greenland and their phylogenetic association within the genus Alexandrium. Harmful Algae 51, 67-80.

Toebe, K., Alpermann, T.J., Tillmann, U., Krock, B., Cembella, A., John, U., 2013a. Molecular discrimination of toxic and non-toxic Alexandrium species (Dinophyta) in natural phytoplankton assemblages from the Scottish coast of the North Sea. Eur. J. Phycol. 48, 12-26.

Toebe, K., Joshi, A.R., Messtorff, P., Tillmann, U., Cembella, A., John, U., 2013b. Molecular discrimination of taxa within the dinoflagellate genus Azadinium, the source of azaspiracid toxins. J. Plankton Res. 35, 225-230.

Vaulot, D., Eikrem, W., Viprey, M., Moreau, H., 2008. The diversity of small eukaryotic phytoplankton $(\leq 3 \mu \mathrm{m})$ in marine ecosystems. FEMS Microbiol. Rev. 32, 795-820.

Vergin, K.L., Beszteri, B., Monier, A., Thrash, J.C., Temperton, B., Treusch, A.H., Kilpert, F., Worden, A.Z., Giovannoni, S.J., 2013. High-resolution SAR11 ecotype dynamics at the Bermuda Atlantic Time-series Study site by phylogenetic placement of pyrosequences. ISME J. 7, 1322-1332.

von Dassow, P., John, U., Ogata, H., Probert, I., Bendif, E.M., Kegel, J.U., Audic, S., Wincker, P., Da Silva, C., Claverie, J.-M., Doney, S., Glover, D.M., Flores, D.M., Herrera, Y., Lescot, M., Garet-Delmas, M.-J., de Vargas, C., 2015. Life-cycle modification in open oceans accounts for genome variability in a cosmopolitan phytoplankton. ISME J., 1-13, (1).

von Quillfeldt, C.H., 2000. Common diatom species in Arctic spring blooms: their distribution and abundance. Bot. Mar. 43, 499-516.

Warns, A., Hense, I., Kremp, A., 2013. Modelling the life cycle of dinoflagellates: a case study with Biecheleria baltica. J. Plankton Res. 35, 379-392, (d).

White, J.W.C., 1990. Climate Change: The IPCC Scientific Assessment. Report Prepared for IPCC Working Group 1. Intergovernmental Panel on Climate Change, Arctic and Alpine Research.

Wickham, H., 2015. plyr: Tools for splitting, applying and combining data. R Packag. version 1.8.3.

Włodarska-Kowalczuk, M., Renaud, P.E., Wȩsławski, J.M., Cochrane, S.K.J., Denisenko, S.G., 2012. Species diversity, functional complexity and rarity in Arctic fjordic versus open shelf benthic systems. Mar. Ecol. Prog. Ser. 463, 73-87.

Yamaguchi, A., Kawamura, H., Horiguchi, T., 2006. A further phylogenetic study of the heterotrophic dinoflagellate genus Protoperidinium (Dinophyceae) based on small and large subunit ribosomal RNA gene sequences. Phycol. Res. 54, 317-329.

Yamaguchi, A., Kawamura, H., Horiguchi, T., 2005. Molecular phylogenetic study of the heterotrophic dinoflagellate genus Protoperidinium (Dinophyceae) inferred from small subunit rRNA gene sequences. Phycol. Res. 53, 30-42.

Zamora-Terol, S., Nielsen, T.G., Saiz, E., 2013. Plankton community structure and role of Oithona similis on the western coast of Greenland during the winter-spring transition. Mar. Ecol. Prog. Ser. 483, 85-102.

Zielinski, O., Voß, D., Meier, D., Henkel, R., Holinde, L., Garaba, S.P., Cembella, A., 2013. Chlorophyll a during Maria S. Merian cruise MSM21/3(ARCHEMHAB).

Zinger, L., Gobet, A., Pommier, T., 2012. Two decades of describing the unseen majority of aquatic microbial diversity. Mol. Ecol. 21, 1878-1896. 